\title{
Wastewater-based epidemiology-surveillance and early detection of waterborne pathogens with a focus on SARS-CoV-2, Cryptosporidium and Giardia
}

\author{
Alireza Zahedi ${ }^{1} \cdot$ Paul Monis $^{2} \cdot$ Daniel Deere $^{3} \cdot$ Una Ryan $^{1}$ (D) \\ Received: 18 November 2020 / Accepted: 14 December 2020 / Published online: 6 January 2021 \\ (C) The Author(s), under exclusive licence to Springer-Verlag GmbH, DE part of Springer Nature 2021, corrected publication 2021
}

\begin{abstract}
Waterborne diseases are a major global problem, resulting in high morbidity and mortality, and massive economic costs. The ability to rapidly and reliably detect and monitor the spread of waterborne diseases is vital for early intervention and preventing more widespread disease outbreaks. Pathogens are, however, difficult to detect in water and are not practicably detectable at acceptable concentrations that need to be achieved in treated drinking water (which are of the order one per million litre). Furthermore, current clinical-based surveillance methods have many limitations such as the invasive nature of the testing and the challenges in testing large numbers of people. Wastewater-based epidemiology (WBE), which is based on the analysis of wastewater to monitor the emergence and spread of infectious disease at a population level, has received renewed attention in light of the current coronavirus disease 2019 (COVID-19) pandemic. The present review will focus on the application of WBE for the detection and surveillance of pathogens with a focus on severe acute respiratory syndrome coronavirus 2 (SARS-CoV-2) and the waterborne protozoan parasites Cryptosporidium and Giardia. The review highlights the benefits and challenges of WBE and the future of this tool for community-wide infectious disease surveillance.
\end{abstract}

Keywords Wastewater $\cdot$ Epidemiology $\cdot$ Cryptosporidium $\cdot$ Giardia $\cdot$ SarsCoV-2

\section{Introduction}

Waterborne diseases are a major threat to public health globally. Worldwide, it is estimated that $\sim 80 \%$ of wastewater is released to the environment without sufficient treatment (UN 2017) and at least 2 billion people use a drinking water source contaminated with faeces (WHO 2019). Waterborne diseases are thought to be responsible for between 1.6 and 12 million deaths annually (Gleick 2002; Troeger et al. 2018; Xagoraraki and O'Brien 2020). Although the burden is the highest in developing countries, outbreaks of disease still occur in

Section Editor: Lihua Xiao

Una Ryan

Una.Ryan@murdoch.edu.au

1 Harry Butler Institute, Murdoch University, Perth, Australia

2 South Australian Water Corporation, Adelaide, Australia

3 Water Futures and Water Research Australia, Sydney, Australia developed countries and the global burden is estimated at 12 billion US dollars per year (Alhamlan et al. 2015). Waterborne pathogens include bacteria (e.g. Escherichia coli, Salmonella spp., Campylobacter spp., Vibrio cholerae), viruses (e.g. norovirus, adenovirus, poliovirus), protozoa (Cryptosporidium spp. and Giardia spp.) and helminths (e.g. Ascaris spp. and Trichuris spp.).

Clinical surveillance and monitoring of waterborne pathogens are essential tools for detecting and preventing further spread and to minimise the extent of an outbreak. However, clinical testing is usually limited to individuals who are ill enough to seek treatment and testing, resulting in underreporting of disease prevalence (Cacciò and Chalmers 2016) and providing a lag indicator for a community outbreak. Similarly, screening for pathogens directly to verify water safety in source and treated waters used for drinking is problematic due to the low pathogen concentrations that are considered acceptable, requiring the analysis of large volumes of water. For instance, acceptable viral pathogen concentrations in treated drinking water range from one infectious virion per $500 \mathrm{kl}$ to $5 \mathrm{ml}$ (Regli et al. 1991; Schijven and Hassanizadeh 
2000; Schijven et al. 2006; Moore et al. 2010). Such concentrations are beyond what is practicably detectable. One solution is to monitor pathogens where they are present at higher concentrations in source waters and make assumptions about pathogen reduction. However, in relatively clean source waters that place little or no reliance on treatment barriers, the acceptable source water concentrations can still be way below the practicable limits of detection, which are in the range one infectious pathogen per 1 to $1 \mathrm{kl}$, depending on the pathogen, assay type and quality of the water. Indeed, most of the standard approaches to pathogen monitoring for both clinical disease and water testing are costly, often pathogen-specific, frequently rely on passive monitoring, are only practicable and affordable at inadequately low frequencies, are subject to biases, and vary widely from country to country depending on the resources and funding available (Ramírez-Castillo et al. 2015; Sims and Kasprzyk-Hordern 2020).

Improved monitoring systems that can detect multiple waterborne diseases across broad communities in a cost-effective manner, preferably in real-time, are therefore urgently required. In this regard, wastewater-based epidemiology (WBE), as an early warning system for a variety of waterborne infectious diseases, has received much recent attention. Initially used for monitoring poliovirus prevalence (Pöyry et al. 1988; Berchenko et al. 2017), community-wide drug abuse (Castiglioni et al. 2006) and other chemical pollutants (Choi et al. 2018), WBE relates broadly to the analysis wastewater for the presence of nucleic acids or other biomarkers excreted in faeces and urine to provide comprehensive community health information (Mao et al. 2020a). The methods will also detect pathogens secreted in saliva, sputum, mucus, vomitus and phlegm - all of which are often captured in wastewater (Deere et al. 2020). Thus, WBE is equivalent to obtaining and analysing a large community-based composite sample of faeces, saliva, vomitus, sputum, urine, shed skin and other material shed during personal cleansing, washing, bathing and excreting, providing a sensitive means of monitoring temporal changes in pathogen concentrations and diversity within a community (Xagoraraki and O'Brien 2020). A further advantage of sampling wastewater directly is that pathogen numbers are higher in wastewater compared with the receiving environments into which wastewaters are discharged.

The emergence in 2020 of the severe acute respiratory syndrome Coronavirus 2 (SARS-CoV-2), which causes viral pneumonia, Coronavirus Disease 2019 (COVID-19), has heightened the focus on WBE as a surveillance tool to provide early detection of disease in the community, particularly due to the time lag between the development of symptoms, clinical diagnosis and any action required by health authorities to contain the disease cluster. Although SARS-CoV-2 typically causes respiratory symptoms, and is shed in nasal, buccal, oesophageal and respiratory discharges into wastewater, it can also result in gastrointestinal symptoms and/or viral shedding in faeces (Wu et al. 2020a, 2020b; Xu et al. 2020), with a meta-analysis of COVID-19 studies finding that $17.6 \%$ of COVID-19 patients had gastrointestinal symptoms and $48.1 \%$ of COVID-19 patients had SARS-CoV-2 RNA detected in their faeces (Cheung et al. 2020). Thus, monitoring the presence of SARS-CoV-2 RNA in wastewater is becoming widely used to track changes in COVID-19 case numbers in communities (e.g. Ahmed et al. 2020a; Bar-Or et al. 2020; Kocamemi et al. 2020; La Rosa et al. 2020a; Medema et al. 2020; Nemudryi et al. 2020; Peccia et al. 2020; Randazzo et al. 2020a, 2020b; Wu et al. 2020a; Wurtzer et al. 2020a, 2020b) (Table 1).

The protozoan parasites, Cryptosporidium and Giardia, are also important enteric pathogens of public health concern and major waterborne pathogens. Between 2011 and 2016, Cryptosporidium and Giardia were responsible for all reported waterborne outbreaks due to protozoa $(n=381)$ worldwide (Efstratiou et al. 2017). Cryptosporidium is the second most important cause of moderate to severe diarrhoea and mortality in children under 5 years of age in developing countries and both symptomatic and asymptomatic cryptosporidial infections in children are associated with malnutrition and stunted growth (Khalil et al. 2018). Oocysts are shed in faeces in high numbers (up to $10^{9}$ per stool); the median infectious doses reported are in the range approximately 1-125 oocysts, depending on species, with a consensus probability of infection per ingested oocyst recommended of $20 \%$; and the oocysts can remain infectious in the environment for more than 6 months under cool, dark, moist conditions (DuPont et al. 1995; Chappell et al. 2006; Shirley et al. 2012; WHO 2016). The global prevalence of Cryptosporidium has been estimated at $7.6 \%$, with an average prevalence of $4.3 \%$ in developed countries and $10.4 \%$ in developing countries (with prevalences as high as $69.6 \%$ in some countries) (Dong et al. 2020). There is evidence that due to under-reporting, the true number of cases in the community may be as much as 500 times higher than the numbers estimated based on routine clinical stool isolates (Hall et al. 2006). Currently, 43 Cryptosporidium species are considered valid (Bolland et al. 2020; Holubová et al. 2020; Ježková et al. 2020), with the majority of human infections caused by $C$. hominis and $C$. parvum, although $>20$ species and genotypes have been reported in humans (Feng et al. 2018; Zahedi and Ryan 2020).

Giardiasis is the most common enteric protozoan parasitic infection worldwide, with an estimated 280 million people infected annually. The species that infects humans, Giardia duodenalis, is a species complex consisting of eight assemblages (A-H), with assemblages A and B the dominant assemblages in humans and assemblages $\mathrm{C}-\mathrm{H}$ in animals, although sporadic cases of assemblages C, D, E and F have been reported in humans (Ryan and Zahedi 2019). Giardia infections can be asymptomatic or result in diarrhoea that can become chronic and has also been associated with irritable bowel syndrome, chronic fatigue and joint pain (Coffey et al. 2020). In infants and children, infections can result in failure to thrive and malnutrition (Dunn and Juergens 2020). In developing 


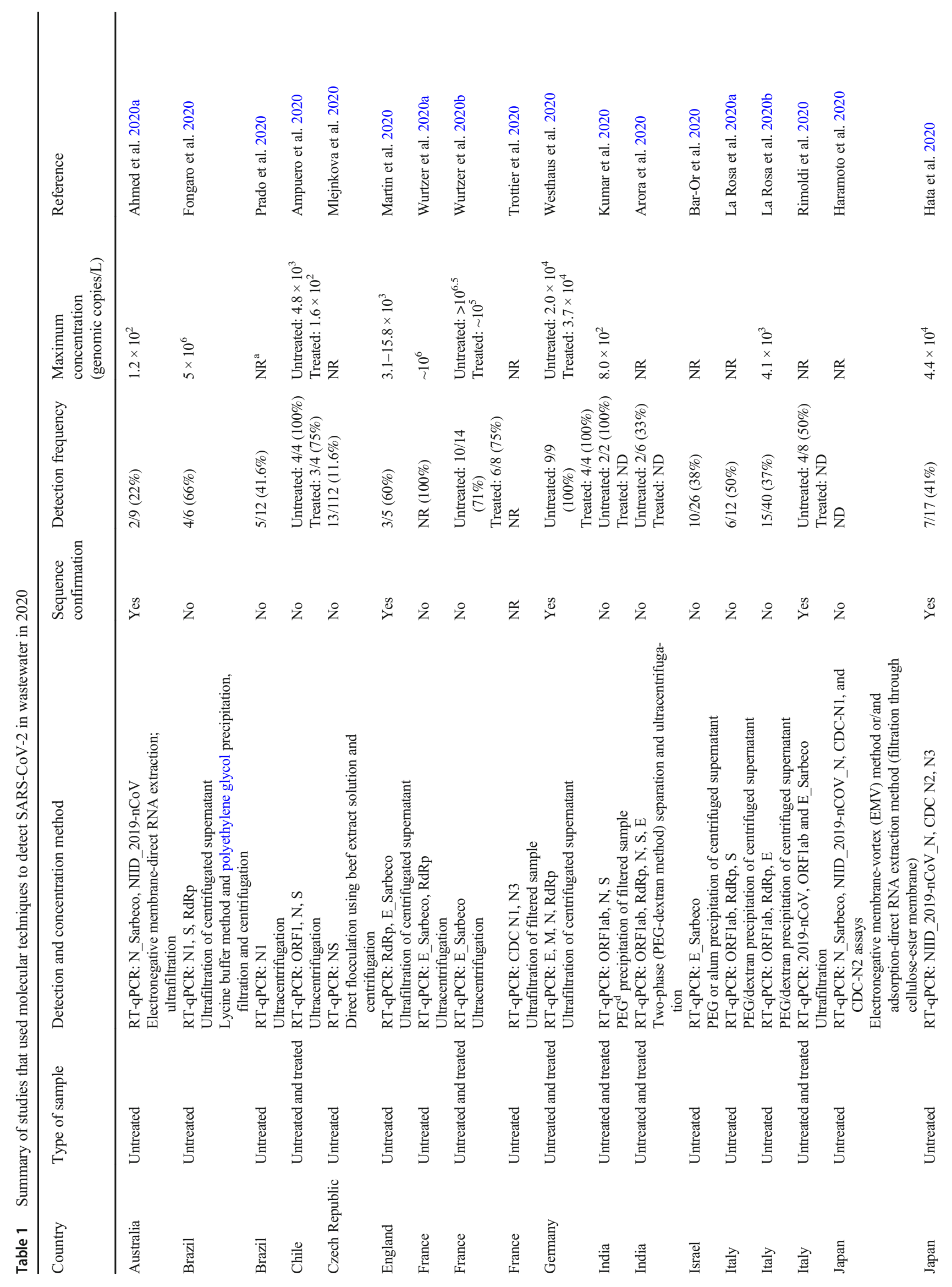




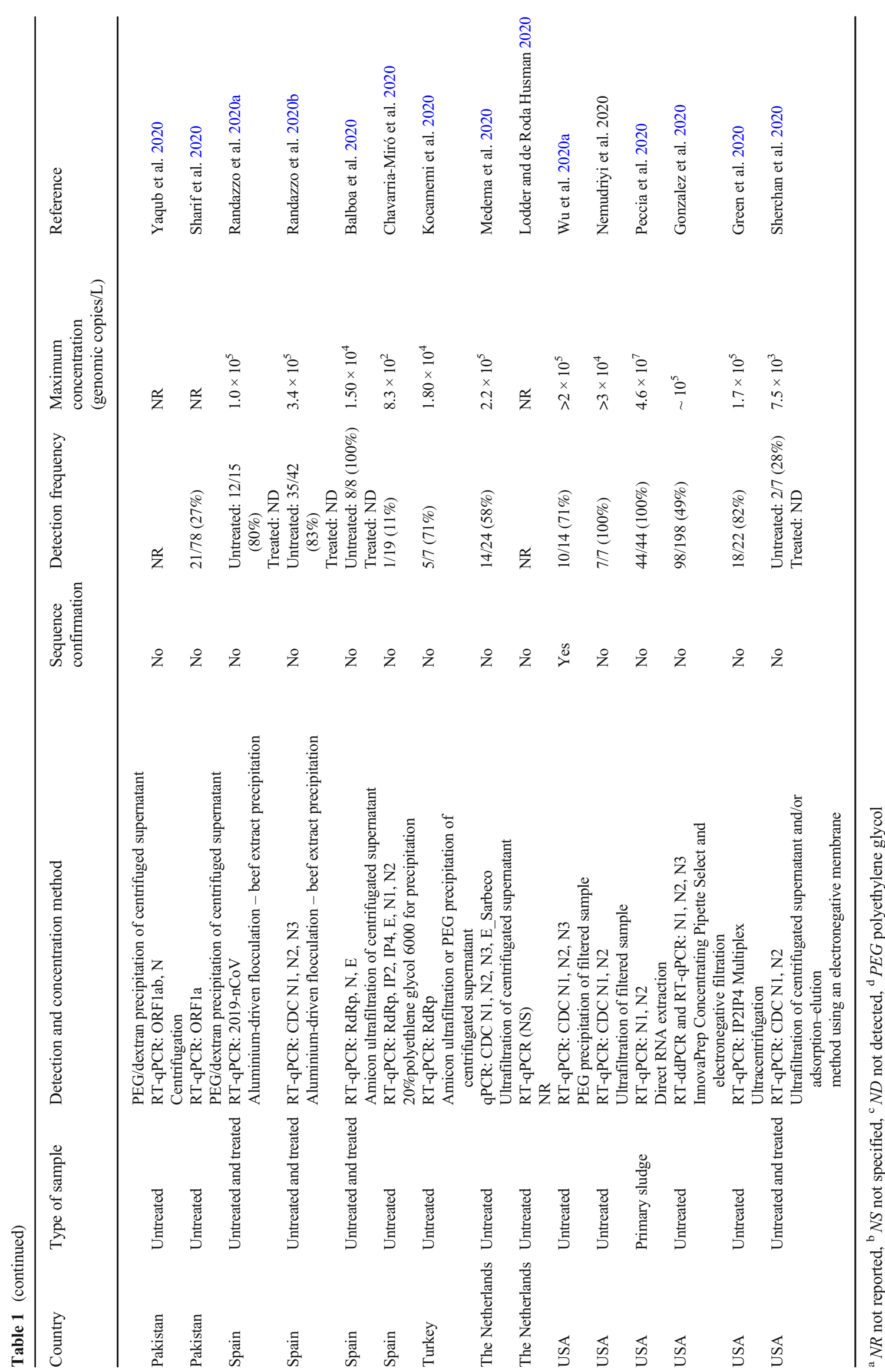

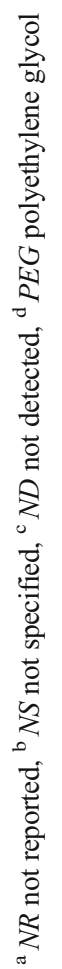


countries, up to $33 \%$ of individuals have been infected and up to $8 \%$ in developed countries (Cacció and Sprong 2014; Dunn and Juergens 2020). As with Cryptosporidium, cysts are shed in the faeces in high numbers (up to $10^{10}$ cysts per day) with a median infectious dose of approximately 25 cysts (Rendtorff 1954, 1979).

Both parasites are prevalent in wastewater (Hamilton et al. 2018; Zahedi et al. 2018; Adeyemo et al. 2019; Razzolini et al. 2020) (Tables 2 and 3), with concentrations in wastewater as high as 60,000 Cryptosporidium oocysts and 100,000 Giardia cysts $\mathrm{L}^{-1}$ (Hamilton et al. 2018), and Cryptosporidium oocysts are resistant to chemical disinfection (Campbell et al. 1995). Urban wastewater discharge is known to play an important role in pathogen transmission. For example, the largest cryptosporidiosis outbreak to date in 1993 in Milwaukee, USA, which affected over 400,000 individuals, was due to drinking water becoming contaminated with wastewater as a result of extreme weather and water treatment failure (MacKenzie et al. 1994). This review will focus on the surveillance and detection of Cryptosporidium, Giardia and SARS-CoV2 in wastewater and the benefits and challenges of WBE for public health.

\section{Occurrence of SARS-CoV-2 in wastewater}

Very limited data is available on the occurrence of the closely related SARS-CoV-1 in wastewater (Peiris et al. 2003; Wang et al. 2005a; Gundy et al. 2009; Wigginton et al. 2015), but connections with wastewater were identified in a 2003 outbreak in Hong Kong linked to a faulty sewage system (Peiris et al. 2003). Since the first report of SARS-CoV-2 in human waste (Holshue et al. 2020), the presence of SARS-CoV-2 in wastewater has drawn substantial attention, and globally an increasing number of studies have detected SARS-CoV-2 in untreated and/or treated urban wastewater and wastewater treatment plants (WWTPs) to track the spatial and temporal dynamics of the virus and the removal of efficiency of wastewater treatment processes (Table 1) and the potential public health risks associated with SARS-CoV-2 in wastewater (Michael-Kordatou et al. 2020). Prevalence rates ranging from 11 to $100 \%$ at a concentration up to $4.6 \times 10^{7}$ genome copies/L in untreated (raw influent), and 0 to $100 \%$ at a concentration up to $10^{5}$ genome copies/L in treated (final effluent) wastewater have been reported (Table 1).

\section{Occurrence of protozoans in wastewater}

The protozoan parasites, Cryptosporidium and Giardia, are among the most common parasites reported in wastewater worldwide and are significant contributors to the global waterborne disease burden (Zahedi et al. 2018) (Tables 2 and 3). The occurrence and distribution of Cryptosporidium oocysts and Giardia cysts in untreated wastewater generally correlates to the infection and excretion rates in the population served, which may also be influenced by the contribution of infected domestic or wild animals to the Cryptosporidium and Giardia load in the raw wastewater (Castro-Hermida et al. 2008; Deere and Khan 2016). To date, studies conducted globally have reported more than 20 species/genotypes of Cryptosporidium and G. duodenalis assemblages A, B, C, E and G in wastewater, with prevalence rates of 11.4 to $100 \%$ and 18.8 to $100 \%$ for Cryptosporidium and Giardia spp., respectively, and often at concentrations over 10 oocysts/L and 100 cysts/L for Cryptosporidium and Giardia, respectively (Tables 2 and 3 ).

Several studies across the world have reported $C$. hominis (the predominant species in humans) among the most prevalent Cryptosporidium species detected in wastewater; e.g. Australia (King et al. 2015a; Zahedi et al. 2018), Brazil and Peru (UlloaStanojlović et al. 2016; Martins et al. 2019), China (Feng et al. 2009; Li et al. 2012; Huang et al. 2017), Japan (Hashimoto et al. 2006; Hirata and Hashimoto 2006), Switzerland and Germany (Ward et al. 2002), the USA (Xiao et al. 2001; Zhou et al. 2003) and Tunisia (Ben Ayed et al. 2012) (Table 2). While in Europe, a number of studies have reported that $C$. parvum is the dominant species in wastewater (Hänninen et al. 2005; Spanakos et al. 2015; Imre et al. 2017; Ramo et al. 2017). In other countries such as China, Iran, Tunisia and the USA, livestock-associated species such as $C$. andersoni and $C$. xiaoi dominate in wastewater samples (Xiao et al. 2001; Liu et al. 2011; Ben Ayed et al. 2012; Hatam-Nahavandi et al. 2016; Ma et al. 2019) (Table 2).

Compared to other assemblages of $G$. duodenalis, assemblages $\mathrm{A}$ and $\mathrm{B}$ have been predominantly reported in wastewater globally, while assemblage C (Yamashiro et al. 2019), E (Castro-Hermida et al. 2011; Ben Ayed et al. 2012; HatamNahavandi et al. 2017) and G (Huang et al. 2017; Ma et al. 2019) have been reported sporadically (Table 3 ).

\section{Current protozoan and SARS-CoV-2 detection/surveillance systems in wastewater}

SARS-CoV-2 is most commonly detected using quantitative reverse transcription polymerase chain reaction (RT-qPCR) assays for the detection of SARS-CoV-2 RNA. To date, more than 17 RT-qPCR assays have been developed for the detection of SARS-CoV-2 in clinical samples including the CDCrecommended 3 gene segments of SARS- CoV-2 RNA (N1, N2 and N3) (CDC 2020) and the envelope protein (E) gene (E Sarbeco, target) (Corman et al. 2020). Some of these assays have been used to detect SARS-CoV-2 in wastewater samples from a wide range of countries including Australia (Ahmed et al. 2020a), Chile (Ampuero et al. 2020), Germany (Westhaus et al. 2020), Israel (Bar-Or et al. 2020), India (Kumar et al. 2020), Italy (La Rosa et al. 2020a), Japan (Hata et al. 2020), France (Wurtzer et al. 2020a, 2020b), the 


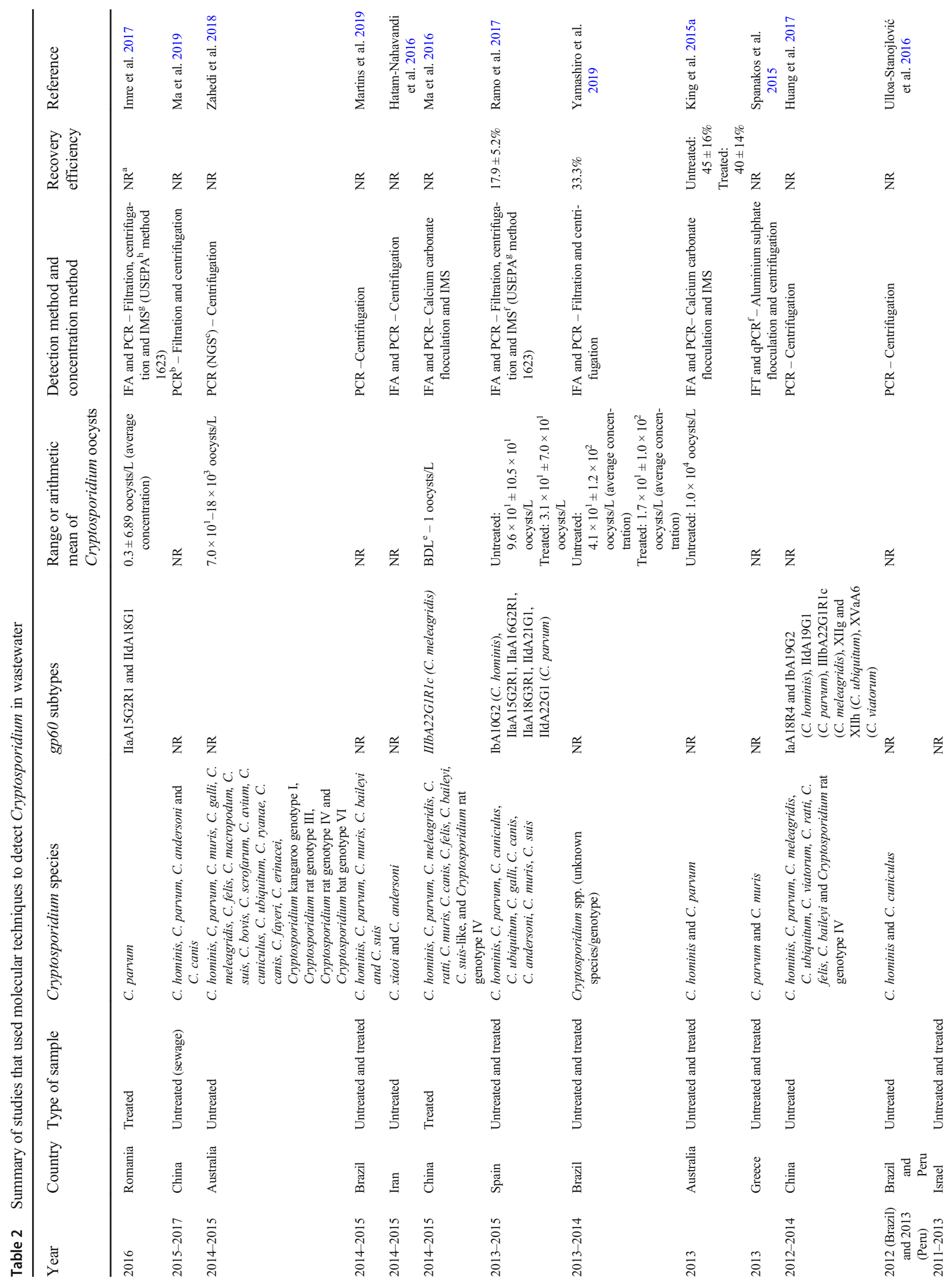




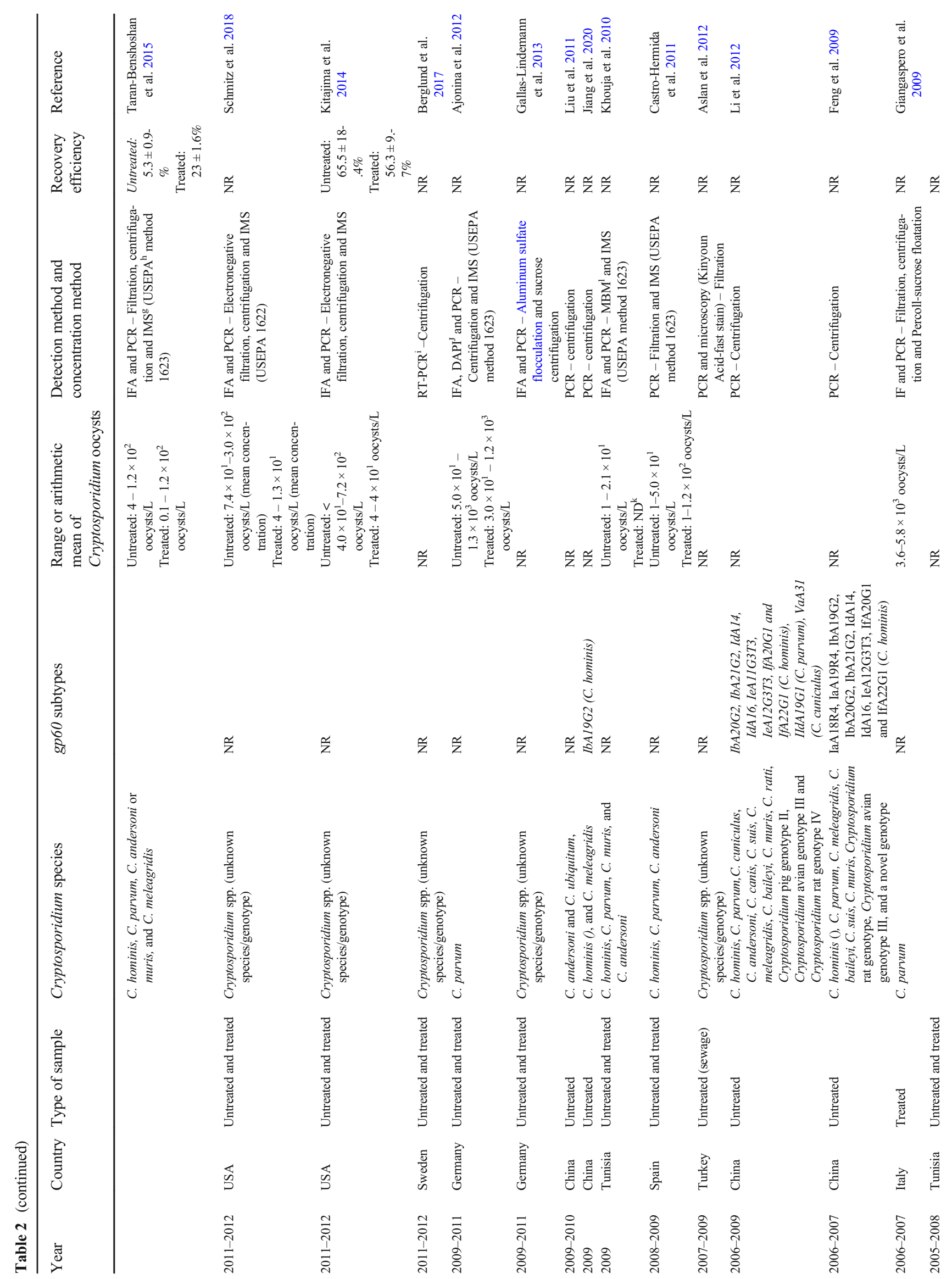




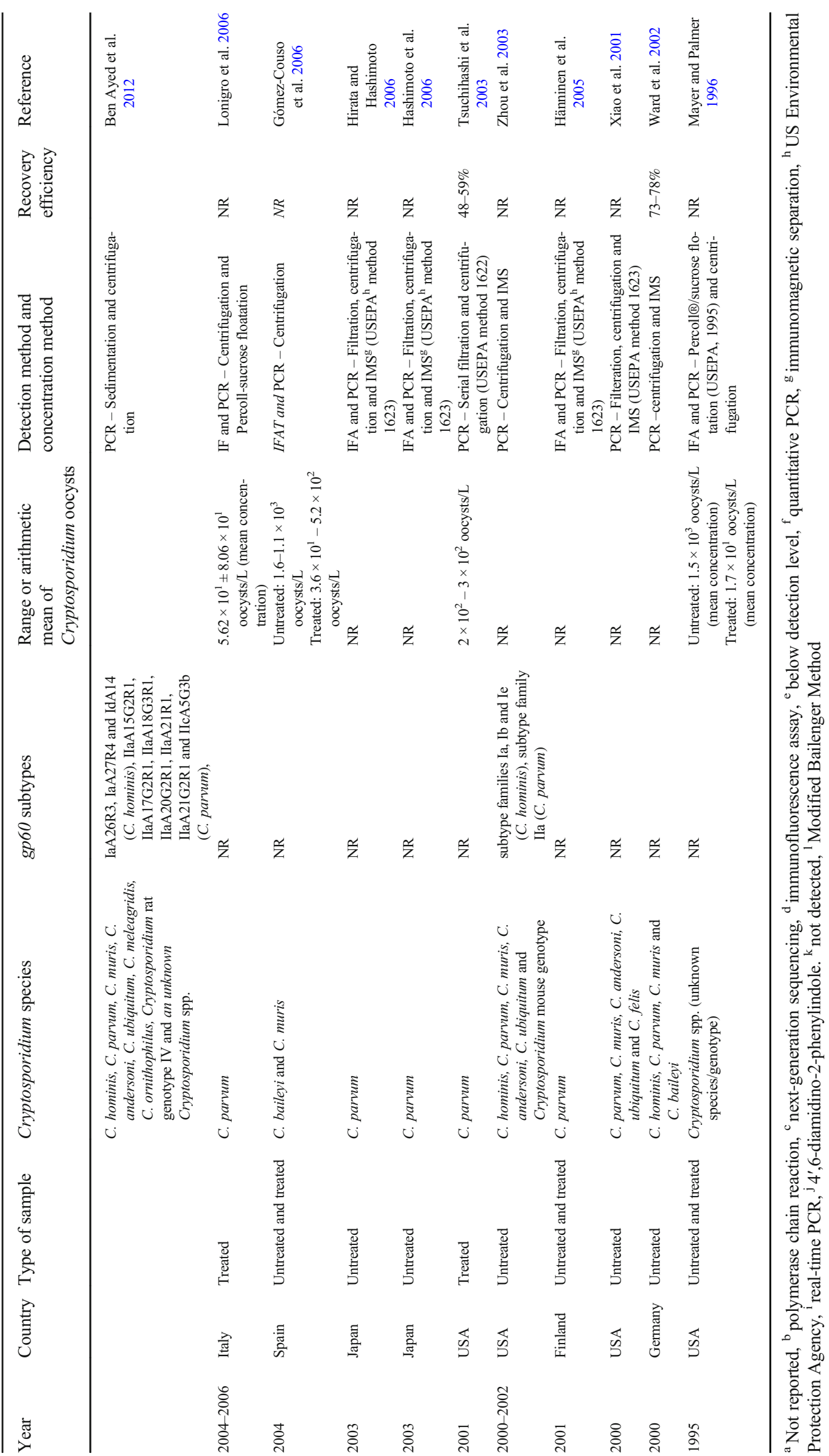


Netherlands (Medema et al. 2020), Spain (Randazzo et al. 2020a, 2020b), Turkey (Kocamemi et al. 2020) and the USA (Green et al. 2020; Nemudryi et al. 2020; Wu et al. 2020a). While qRT-PCR is the most reliable method to detect SARS-CoV-2, a variety of serological tests (ELISAs, lateral flow assays etc) have also been developed, which provide additional important information on the kinetics of the immune response and detection of asymptomatic infections and have the advantage that virus proteins are more stable than RNA (La Marca et al. 2020). Antibody-based methods have been applied for the detection of SARS-CoV-2 protein in wastewater using immunoblotting and immune-linked PCR (Neualt et al. 2020).

Prior to detection, studies have used a variety of viral concentration methods including ultrafiltration, polyethylene glycol (PEG) precipitation, filtration with an electronegative membrane and centrifugation ( $\mathrm{Lu}$ et al. 2020) (Table 1). To enable accurate measurements of SARS-CoV-2 in wastewater, it is important to determine the recovery efficiencies of these methods. A recent study compared the efficiency of different viral concentration methods from WWTPs using murine hepatitis virus as a human coronavirus $(\mathrm{CoV})$ surrogate (Ahmed et al. 2020b, 2020c). Of these, the highest mean recovery $(65.7 \%)$ was achieved using an adsorption-extraction method, supplemented with $\mathrm{MgCl}_{2}$, followed by an adsorption-extraction method without $\mathrm{MgCl}_{2}(60.5 \%)$. Mean recovery efficiencies for PEG precipitation (44\%) and ultrafiltration (Amicon ${ }^{\circledR}$ Ultra-15 - 28\%, Centricon Plus-70 $56 \%$ ) were lower (Ahmed et al. 2020b). Concentration of both liquid and solid fractions of wastewater samples (due to viral particle adsorption to organic matter) and avoiding acidification of samples was identified as important for viral recovery (Ahmed et al. 2020b).

Standard detection methods for Cryptosporidium and Giardia in wastewater involve concentration (using filtration or flocculation) and purification of the oo(cysts) (usually using immuno magnetic separation-IMS), followed by immunofluorescent microscopy and enumeration, based on Method EPA 1693/2014 (USEPA 2014). The recovery efficiency from wastewater varies widely and ranges from $5.5 \%$ to as high as $100 \%$ with mean recoveries of $62 \%$ (Cryptosporidium) and 45\% (Giardia) (Gennaccaro 2003; Quintero-Betancourt et al. 2003; Robertson et al. 2006; Nasser et al. 2012; Nasser 2016; Yamashiro et al. 2019). However, a major limitation of standard microscopy-based detection methods is that they do not provide information on the species/assemblages. Vital dyes have been used to determine viability but are problematic and subject to overestimation of oo(cyst) viability (Sammarro Silva and Sabogal-Paz 2020). As a consequence, more recent studies have employed molecular detection methods for genetic characterisation, or cell culture infectivity assays.
Relatively few studies have genetically characterised Cryptosporidium and Giardia in wastewater (Tables 2 and 3) and most studies have utilised Sanger sequencing of PCR amplicons with only two studies using next-generation sequencing (NGS) of amplicons (Zahedi et al. 2018, 2019). A custom microarray targeting a range of viral, bacterial and protozoan pathogens has also been tested against DNA obtained from whole genome amplification (WGA) of RNA and DNA from wastewater and animal faeces, which detected Giardia but not Cryptosporidium (Li et al. 2015).

A wide diversity of Cryptosporidium and Giardia species and assemblages have been detected in wastewater with many studies reporting $C$. hominis as well as $C$. parvum, $C$. muris, C. meleagridis and $G$. duodenalis assemblages $\mathrm{A}$ and $\mathrm{B}$ among the most prevalent (King et al. 2015a; TaranBenshoshan et al. 2015; Ulloa-Stanojlović et al. 2016; Huang et al. 2017; Ramo et al. 2017; Zahedi et al. 2018; Yamashiro et al. 2019) (Tables 2 and 3). In addition, a few studies have utilised subtyping tools to further investigate Cryptosporidium gp60 subtypes in wastewater (Feng et al. 2009; Ben-Ayed et al. 2012; Li et al. 2012; Ma et al. 2016; Huang et al. 2017; Jiang et al. 2020). Amongst $C$. hominis subtype families identified in wastewater to date, subtype family $\mathrm{Ib}$ was the most predominant subtype family reported ( $83 \%$ of studies that used subtyping), followed by subtype families Ia (66\%), Id and Ie (50\% each) and If (33\%). For C. parvum, only three studies have used subtyping tools, and C. parvum subtype families IIa (Tunisia and USA), IIc (Tunisia) and IId (China) were reported (Zhou et al. 2003; Ben Ayed et al. 2012; Li et al. 2012; Huang et al. 2017). In addition, subtyping of $C$. meleagridis, C. viatorum and C. ubiquitum in wastewater samples at the gp60 locus have identified subtypes IIIbA22G1R1c, XvaA6 and two distinct subtype families XIIg and XIIh, respectively (Ma et al. 2016; Huang et al. 2017) (Table 2).

\section{Fate/survival/removal of protozoans and SARS-CoV-2 in wastewater}

After being shed into nasal, buccal, oesophageal, respiratory and faecal discharges into wastewater, pathogens are exposed to the wastewater environment for hours to days before they reach WWTPs. The fate and survival of pathogens in wastewater systems depend on a variety factors, including wastewater characteristics, the presence of biofilms, temperature, $\mathrm{pH}$, average in-sewer travel time, per-capita water use, and the processes used to treat and disinfect the wastewater (Curtis 2003; Cao et al. 2020; Hart and Halden 2020; Mandal et al. 2020). Wastewater treatment usually involves a combination of physical (sedimentation, filtration, inactivation by solar or UV radiation), biological (activated sludge, algae) and chemical (coagulation-flocculation, inactivation by 
oxidants such as chlorine) processes for pathogen removal from wastewater, with some of the process occurring concurrently (Bhatt et al. 2020; Fu et al. 2010; Nasser et al. 2012).

In general, secondary wastewater treatment is capable of removing an average of $1-\log _{10}(90 \%)$ of viruses, although removal levels are highly variable and additional treatment such as chlorination is required to reduce virus levels to safe levels for release to the environment (McLellan et al. 2020). Relatively, little is known about the fate of SARS-COV-2 in WWTPs. In one study, the time from stool emission to the arrival at the WWTP for SARS-CoV-2 was estimated at 6-8 h (Rimoldi et al. 2020) and it has previously been reported that SARS-CoV-1 can remain infectious in wastewater for up to 14 days (at $4{ }^{\circ} \mathrm{C}$ ) (Wang et al. 2005a). Coronaviruses are enveloped viruses, which means that the virus genome and associated proteins are covered by a lipid membrane taken from the host cell during virus reproduction (Casanova et al. 2009; Schoeman and Fielding 2019). In contrast, enteric viruses such as noroviruses and enteroviruses are nonenveloped, and their genome is encapsulated by a protein coat. These structural differences alter their behaviour, with enveloped viruses more readily binding to particulates in wastewater compared with non-enveloped viruses, which are not particle associated (Ye et al. 2016). Enveloped viruses are considered to be more fragile compared with non-enveloped viruses because the presence of compounds such as solvents and detergents in wastewater can damage the virus envelope, rendering them non-infectious (Gundy et al. 2009). Wastewater temperature varies seasonally and it has been estimated that at $20{ }^{\circ} \mathrm{C}$, at least $25 \%$ of SARS-COV-2 virus RNA in wastewater should persist even with an in-sewer transit time of $10 \mathrm{~h}$ and low virus stability (Hart and Halden 2020). Chlorination is the most commonly used disinfection technique in WWTPs and previous studies have shown that SARS-CoV-1 is more sensitive to disinfection than Escherichia coli, with complete inactivation at a dose of $10 \mathrm{mg} / \mathrm{L}$ chlorine or $20 \mathrm{mg} / \mathrm{L}$ chlorine dioxide (Wang et al. 2005b). A study in Italy detected SARS-CoV-2 RNA in raw, but not in tertiary treated wastewaters and none of the positive samples contained infectious virus (Rimoldi et al. 2020), which is similar to a study in Spain (Randazzo et al. 2020b). A study in Paris identified SARS-CoV-2 RNA in raw (23/23) and treated (6/8) wastewater, but there was a 100 -fold reduction in viral load in treated water compared to raw water (Wurtzer et al. 2020b).

The removal of Cryptosporidium and Giardia (oo)cysts at WWTPs can be highly variable and often dependent on the temperature and type of wastewater treatment processes used (Emelko 2003; Nasser et al. 2012; 2016; King et al. 2017; Hamilton et al. 2018; Schmitz et al. 2018). Seasonality and inflow also affect removal (King et al. 2017), and many studies have reported variable removal of both Cryptosporidium and Giardia from WWTPs, particularly activated sludge
(Nasser et al. 2012; 2016). Giardia $\log _{10}$ reduction values (LRV) removal efficiencies of 0.5-4.0 (Taran-Benshoshan et al. 2015; Soller et al. 2017; Hamilton et al. 2018; Yamashiro et al. 2019) and Cryptosporidium LRVs ranging from 0.21 to 3.08 (King et al. 2017; Soller et al. 2017; Hamilton et al. 2018) have been reported from various WWTPs. WWTPs that used Bardenpho processes (similar to activated sludge but incorporates additional aerobic (oxic) and anoxic stages) have been reported to have had significantly greater LRVs for Cryptosporidium and Giardia than WWTPs using activated sludge or other methods (Schmitz et al. 2018).

Few studies have measured the extent of protozoan inactivation that may be occurring across treatment processes. An integrated Cryptosporidium assay that determines oocyst density, infectivity and genotype has been developed (Swaffer et al. 2014; King et al. 2015a, 2017) and applied to wastewater (King et al. 2015b, 2017). Using this assay, King et al. (2017) showed that Cryptosporidium oocyst infectivity in wastewater in two states in Australia were stable throughout the year but that removals across secondary treatment processes were seasonal and highly variable (King et al. 2017). Interestingly, the infectivity of oocysts that were not removed in the effluent was higher compared to inlet samples for some WWTPs analysed, possibly due to the preferential removal of damaged/non-infectious oocysts. Another study reported that while activated sludge removed $\sim 80 \%$ of oocysts, the remaining oocysts were still infectious in mice (Villacorta-Martínez de Maturana et al. 1992), which highlights the importance of incorporating routine infectivity testing in wastewater (King et al. 2017). Ultrafiltration (Cryptosporidium: 4.4-6.0 LRV; Giardia: 4.7-7.4 LRV) and UV disinfection combined with advanced oxidation ( 6.0 LRV for both Cryptosporidium and Giardia) were reported as the most efficient methods for removal and disinfection of Cryptosporidium and Giardia (oo)cysts in WWTPs (Soller et al. 2017). Future studies on environmental conditions including temperature and $\mathrm{pH}$ and other wastewater treatment processes and disinfection studies are necessary to better understand the removal of a range of pathogens from WWTPs (Bhatt et al. 2020).

\section{Benefits of wastewater-based epidemiology}

Normally, disease outbreaks are detected and their progression monitored by the clinical testing of symptomatic individuals. However, particularly in the case of enteric pathogens, outbreaks can be missed or disease incidence under-reported because there is a reliance on infected people presenting for medical care, and for medical practitioners to request clinical testing to confirm infection and to report results (Cacciò and Chalmers 2016). In the case of the COVID-19 pandemic, many countries adopted large-scale screening of people with flu-like symptoms to identify COVID-19 cases and assist with 


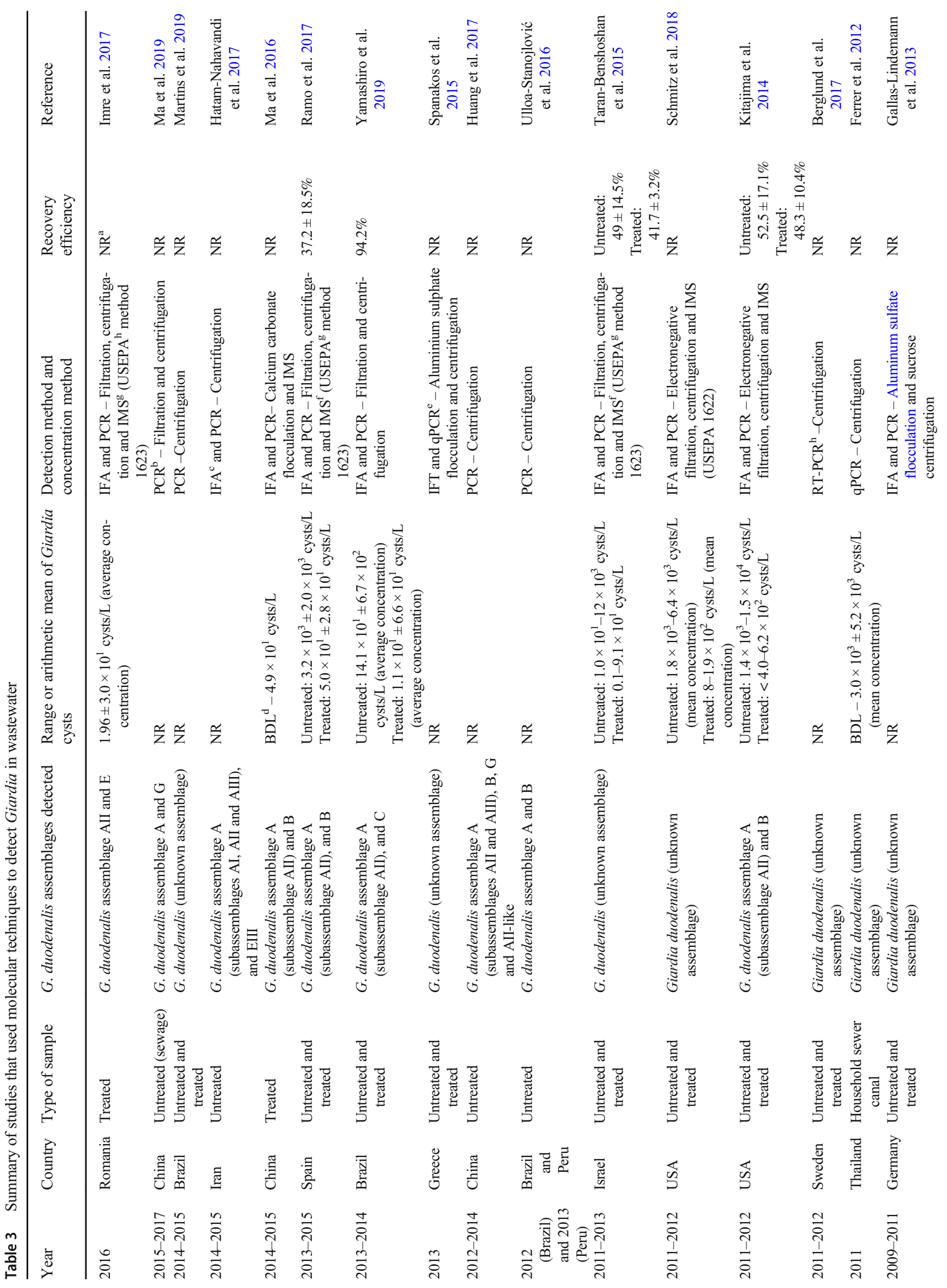




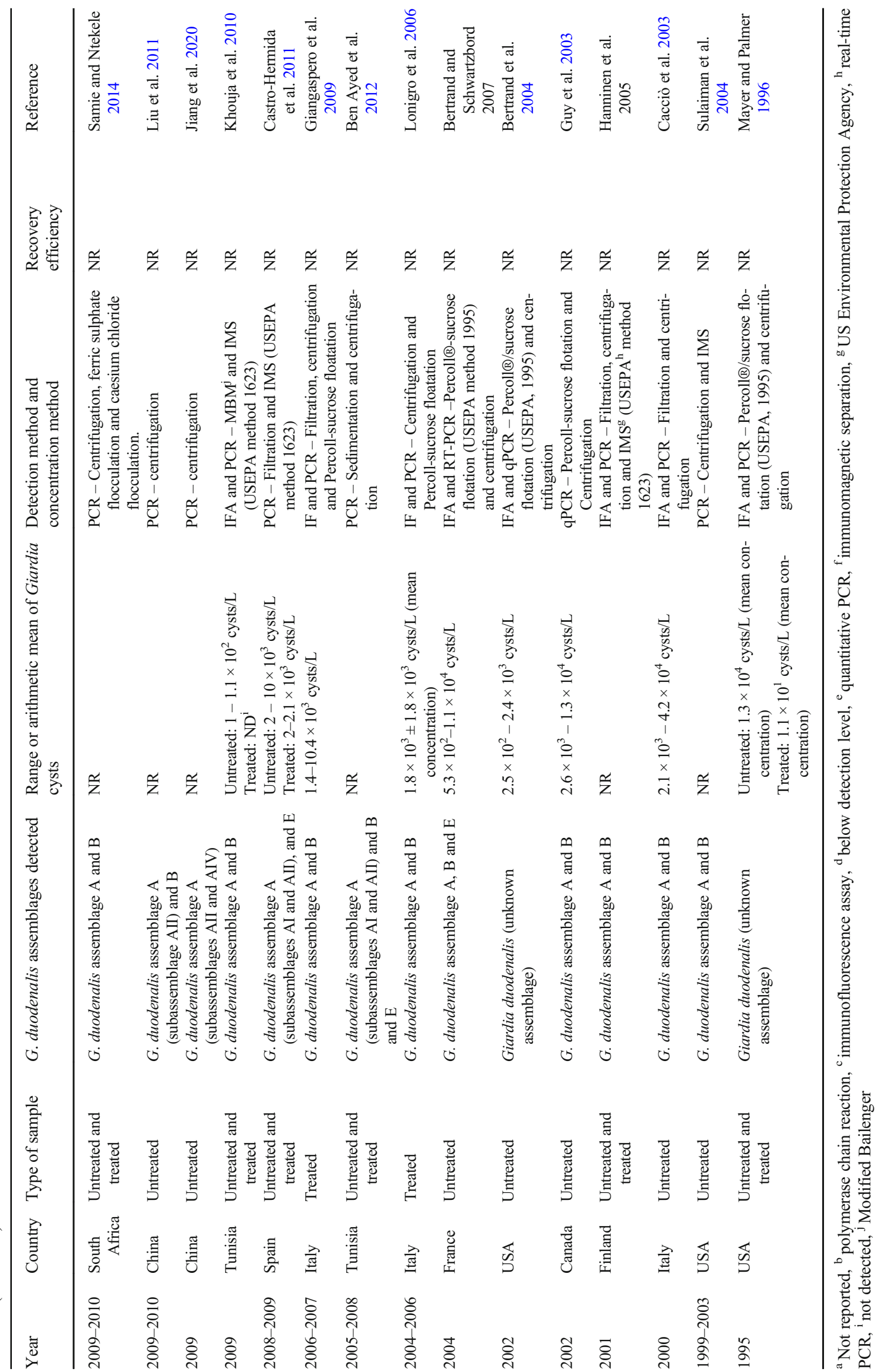


disease containment, overwhelming the testing capacity of many public health systems and also causing global shortages of testing reagents. As pathogens such as viruses (e.g. SARSCoV-2) and protozoa (Cryptosporidium and Giardia) are shed through faeces into wastewater, continuous and systematic monitoring of WWTPs can clearly benefit public health by providing early warning signs and information about temporal and spatial spread of infection in different localities at a population level (Kitajima et al. 2020).

Several WBE studies have reported the occurrence of local community transmission of SARS-CoV-2 before the first notified autochthonous SARS-CoV-2 cases (La Rosa et al. 2020a; Medema et al. 2020; Randazzo et al. 2020a, 2020b). Had this testing been in place at the time, it would have provided public health officials with more time to coordinate and implement actions to slow the spread of disease. A study in the UK reported that clinical testing underestimated the prevalence of COVID-19 and that large reductions in SARSCoV-2 RNA in wastewater coincided with lockdowns (Martin et al. 2020).

Similarly, analyses of wastewater in Australia for Cryptosporidium identified a large increase in oocyst numbers relating to an outbreak of cryptosporidioisis, prior to it being reported by public health officials (King et al. 2017). WBE has also been used in several studies to show that the community level prevalence of Giardia is underestimated (Jakubowski et al. 1991; Oda et al. 2005; Nasser et al. 2012).

The lag time between symptoms developing and clinical testing varies depending on a number of factors including willingness of individuals to present for testing, workloads in testing facilities etc., but is usually 3-9 days after symptom onset. One study in the US reported that WBE for SARSCoV-2 foreshadowed new clinical case reports by $2-4$ days (Nemudryi et al. 2020) and another that viral titre trends in wastewater appeared 4-10 days earlier in wastewater than in clinical data (Wu et al. 2020b). In addition to this lag time, clinical testing for SARS-CoV-2 underestimates the true scale of the pandemic, as another US study estimated that only $32 \%$ of SARS-CoV-2-infected individuals sought medical care (Silverman et al. 2020). WBE overcomes this by capturing data from all individuals in the community. WBE can also detect asymptomatic community infections and rapidly identify emerging clusters which can then be used to alert public health officials about emerging undetected transmission events (Tang et al. 2020).

In addition, WBE can be used to monitor the effectiveness of public health interventions. For example, a study in Cuba detected poliovirus in $100 \%$ of wastewater samples prior to an immunization campaign, but 15 weeks after the campaign, no virus was detected (Más Lago et al. 2003). Similarly, WBE could be used to monitor the ongoing effectiveness of public health campaigns to reduce COVID-19 by tracking increases or decreases in disease burden, or to detect the re-emergence of disease in communities that have no active COVID-19 cases. Carefully designed spatial sampling and nationwide WBE monitoring could be used to identify and monitor sensitive locations, such as aged care facilities, or to generate maps of disease clusters and show patterns of disease and identify which public health interventions are more effective than others (Daughton 2020). Communities with high numbers of a particular pathogen identified could be targeted for more focussed testing and in the longer term to identify and mitigate causes, e.g. socioeconomic status, age demographics, etc. (Sims and Kasprzyk-Hordern 2020).

Sequencing and phylogenetic analysis of pathogens in wastewater allows for comparisons between regions and detection of sources of infection and transmission dynamics. This is very much in its infancy for SARS-CoV-2 in wastewater, but is actively being used in identifying and tracing sources of COVID-19 as part infection control strategies (Rockett et al. 2020). Such an approach may be particularly useful in settings with low disease incidence when the source of new infection clusters is being tracked (Eden et al. 2020). A comprehensive study using WGS assessed the geographic and temporal distribution of SARS-CoV-2 lineages across Europe (Alm 2020) and this approach was used in the Netherlands to identify separate introductions to mink farms (Oreshkova et al. 2020). A study in England used WBE to detect virus variants that were particularly prevalent in the UK and also identified the increasing dominance of the Spike protein G614 variant using Whole Genome sequencing (WGS) (Martin et al. 2020). Similarly, phylogenetic analyses of a SARS-CoV-2 genome from a WWTP in Bozeman, Montana (USA), showed that it was more closely related to isolates from California and Australia than the Wuhan WA1 linage (Nemudryi et al. 2020). Surveillance using WGS has also been used to show that infections in California have been due to multiple introductions from interstate and international sources (Deng et al. 2020).

Subtyping of Cryptosporidium from wastewater in China has been used to identify differences in the transmission dynamics of $C$. hominis from different cities (Li et al. 2012). In the same way, molecular analyses have been used to identify that hospitals are important contributors of Cryptosporidium and Giardia to urban wastewater (Jiang et al. 2020). Molecular typing of Cryptosporidium in wastewater has also been used to identify the contribution of abattoirs to wastewater as species from livestock such as $C$. andersoni (Zhou et al. 2003; Ben Ayed et al. 2012) and species from poultry (C. galli, C. baileyi and C. meleagridis) (Huang et al. 2017; Ramo et al. 2017; Zahedi et al. 2018) are more frequently detected in cities with large abattoirs. WBE has identified the persistence of the $C$. hominis IbA10G2 subtype, which was responsible for the 1993 Milwaukee outbreak (Zhou et al. 1993). A study conducted 7 years after the outbreak identified that despite the complexity of Cryptosporidium in 
wastewater, the IbA10G2 subtype was still the predominant subtype indicating its persistence even in the absence of another outbreak (Zhou et al. 1993). WBE has also been used to show that anthroponotic and not zoonotic transmission of Giardia dominates in cities in China due to the absence of detection of animal-specific Giardia assemblages and even when potentially zoonotic assemblages (A) were detected, subtyping identified sub-assemblage AII, which is mainly found in humans ( $\mathrm{Li}$ et al. 2012). Due to the diversity of pathogens from different sources in wastewater, NGS has advantages over conventional Sanger sequencing in identifying the extent of diversity and also detecting low abundance species that may not otherwise be detected by conventional sequencing. For example, NGS has been shown to detect a larger diversity of Cryptosporidium species and subtypes in Australian wastewater compared to Sanger and identified striking differences between states, reflecting differing contributions from humans, livestock, wildlife and birds and abattoirs to wastewater (Zahedi et al. 2018).

\section{Challenges, risks and future prospects}

Despite the obvious benefits of WBE, many challenges remain. Concentrations of pathogens in wastewater can vary seasonally and daily, depending on a wide variety of factors including the disease prevalence and age and health status in communities, the rate at which the pathogens are shed into the wastewater in nasal, buccal, oesophageal, respiratory and faecal discharges, climate and environmental factors including rainfall, the relative proportions of industrial and domestic effluent, water use and wastewater management practices including sewer residence and holding times. The impacts of all these factors need to be better understood to improve the predictive value of WBE.

It is particularly important to better understand how and in what quantities pathogens are shed in the nasal, buccal, oesophageal, respiratory and faecal discharges from infected individuals that might enter wastewater streams in order to model the number of infections in the community using the numbers of pathogen detected in wastewater. For example, defecation frequency is the highest in the morning (Heaton et al. 1992) and therefore the timing of sampling is important, as morning samples are likely to contain higher numbers of faecal-oral pathogens. In addition, pathogen shedding is frequently sporadic. For instance, not all COVID-19 patients shed virus in their faeces. A recent meta-analysis of ninetyfive studies reported that 43\% (934/2149) of patients (including asymptomatic patients) tested positive for SARS-CoV-2 in stool samples but the prevalence of positivity from faecal samples varied widely across studies (van Doorn et al. 2020). The viral load of SARS-CoV-2 in the faeces of patients also varies widely depending on the infection course, with up to
$10^{8}$ copies per gram of faeces (Foladori et al. 2020; Lescure et al. 2020; Pan et al. 2020; Wölfel et al. 2020). Similarly, both Cryptosporidium and Giardia also exhibit sporadic (oo)cyst shedding in faeces (Danciger and Lopez 1975; Chappell et al. 1996) and as with SARS-CoV-2, the (oo)cyst faecal load also varies widely with up to $10^{5-7}$ Cryptosporidium oocysts per gram of faeces (Chappell et al. 1996).

It is also unclear how long the shedding continues in faeces once other symptoms have resolved. For primarily upper respiratory and nasopharyngeal pathogens, shedding from nasal, buccal, oesophageal and respiratory discharges into wastewater are relevant as well as faecal inputs. Other pathogens, such as norovirus, are often shed in vomitus (Kirby et al. 2016). As regards SARS-CoV-2, initial studies report that faecal shedding is relevant to wastewater samples since faecal samples were positive between 1 and $>30$ days (up to 7 weeks) post onset of illness and the median survival of positive viral signals was significantly longer in faecal samples than that in oropharyngeal swabs (Amirian 2020; Wang et al. 2020). With Cryptosporidium, oocyst shedding post cessation of diarrhoea is very variable and can extend for up to 60 days (Jokipii and Jokipii 1986; Stehr-Green et al. 1987) and for up to 6 months with Giardia (Hanevik et al. 2007).

Efficient recovery and concentration of pathogens from WWTPs prior to identification is central to reliable detection. Currently, there are differences in the types and volumes of samples analysed and differences in the concentration and processing procedures and detection methods used between studies. In order to make WBE studies more comparable, a standard approach for WBE including robust sample design and quality assurance protocols is essential (Ahmed et al. 2020d; Farkas et al. 2020). Studies to develop a simple, effective primary concentration method that can be used for the concentration of viral, bacterial and eukaryotic pathogens are also vital. Central to this is the ability to determine recovery efficiencies for the different pathogens monitored as without this, accurate quantitation and determination of the numbers of pathogens present in WWTPs is not possible. Whatever methods are developed for real-time WBE detection in the future, they need to be fully quantitative to allow for comparison across communities. If detection methods are nucleic acid based, then standardised extraction and PCR-based diagnostic methods should be used.

Understanding the detection limits of WBE is also an area that requires more study (i.e. what numbers of cases need to be positive in a community before they can be confidently detected at a WWTP). Modelling suggests that for SARS-CoV2 , detection in community wastewater of one positive case per 100 to 2,000,000 non-infected people is theoretically feasible (Hart and Halden 2020; Kitajima et al. 2020). A study in Japan reported that SARS-CoV-2 RNA could be detected in WWTPs when the number of total confirmed cases was as low as 1 in 100,000 people but that detection frequency 
increased and became more reliable once cases were at 10 in 100,000 people or higher (Hata et al. 2020). The detection limits for other pathogens remain unknown.

While some studies have reported that the prevalence in wastewater correlated well with the reported COVID-19 community prevalence (Ahmed et al. 2020a; Medema et al. 2020; Wurtzer et al. 2020a, 2020b), another study reported that SARS-CoV-2 concentrations in wastewater were orders of magnitude greater than the number of confirmed clinical cases (Wu et al. 2020a). The impact of confounding variables such as the rate of asymptomatic cases and the variation in numbers of individuals that present for testing as well as the testing and quantitation methods used are also variables that require further study to provide more robust data in this area. Another challenge associated with WBE is estimating the population size of individual WWTP catchments and the contribution of tourists or commuters in smaller communities (Sims and Kasprzyk-Hordern 2020). Ethical considerations, including privacy and the stigmatisation of ethnic and vulnerable populations, are also issues that will need to be managed. Analyses based on populations over $>10,000$ are thought to provide anonymity; however, reporting the emergence and/or spread of disease in small populations or sub-populations by WBE must be done with care and needs to be sensitive to different social, ethnic and economic circumstances (Sims and Kasprzyk-Hordern 2020).

Although RT-PCR is the most widely used method for detecting SARS-CoV-2, it can be expensive, timeconsuming and requires skilled technicians, and is therefore not conducive to real-time WBE. A variety of point-of-care (POC) options are being explored including paper-based devices (e.g. those that use inexpensive isothermal nucleic acid amplification on a paper material) (Mao et al. 2020b). However, available data indicates that current isothermal amplification of SARS-CoV-2 lacks the required sensitivity and throughput and still requires sample concentration prior to analyses. CRISPR (clustered regularly interspaced short palindromic repeats)-based isothermal RNA detection assays has been developed to help overcome some of these issues but are expensive and the sensitivity remains to be fully evaluated (Broughton et al. 2020; Huang et al. 2020). Small-scale labon-a chip biosensor devices which use a bio-recognition element (e.g., antibodies, aptamer, peptides, protein, etc.) that can generate physicochemical signals (optical, electrochemical, etc.) are increasingly being developed for pathogen detection (Ryan et al. 2017; Cesewski and Johnson 2020), including Cryptosporidium (Luka et al. 2019) and SARS-CoV-2 (Funari et al. 2020; Mavrikou et al. 2020; Qiu et al. 2020; Seo et al. 2020). Biosensors have the potential for rapid and real-time WBE and have been applied to wastewater (Yang et al. 2017), but still present many technical challenges including sensitivity, specificity and detection limit (Ryan et al. 2017; Cesewski and Johnson 2020; Mao et al. 2020c).
Moreover, as discussed above, we need to better understand the infectiousness, half-life and survival of various pathogens in wastewater as well as the travel time to the treatment facility, water use per capita and the effectiveness of various WWTP processes and disinfection technologies (chlorine, $\mathrm{UV}$, ozone etc) on the removal of a wide range of pathogens to better inform computational models (Ahmed et al. 2020a, 2020d; Hart and Halden 2020; Mandal et al. 2020).

\section{Conclusions}

WBE has the potential to be a powerful and effective early warning tool for community-wide monitoring of public health. However, improved assays for pathogen concentration, detection, quantitation and infectivity are needed for continuous and systematic monitoring of WWTPs. WBE also needs to be integrated with clinical testing, case reporting and public health campaigns, including coordination of testing methods, so that data generated from WBE and clinical testing is comparable. Recently, a global COVID-19 WBE Collaborative project has been launched (www. covid19wbec.org/) in collaboration with the Sewage Analysis CORe group Europe (SCORE) network and the Global Water Pathogen Project to coordinate methodological research and reporting on WBE. Based on this precedent, similar collaboration in relation to the monitoring of protozoan and other pathogens in wastewater is highly desirable. Molecular sequencing and typing of pathogens in wastewater holds great promise for identifying sources of infection and determining transmission dynamics.

\section{Compliance with ethical standards}

Competing interests The authors declare that they have no competing interests.

\section{References}

Adeyemo FE, Singh G, Reddy P, Bux F, Stenström TA (2019) Efficiency of chlorine and UV in the inactivation of Cryptosporidium and Giardia in wastewater. PLoS One 14(5):e0216040

Ahmed W, Angel N, Edson J, Bibby K, Bivins A, O'Brien JW, Choi PM, Kitajima M, Simpson SL, Li J, Tscharke B, Verhagen R, Smith WJM, Zaugg J, Dierens L, Hugenholtz P, Thomas KV, Mueller JF (2020a) First confirmed detection of SARS-CoV-2 in untreated wastewater in Australia: a proof of concept for the wastewater surveillance of COVID-19 in the community. Sci Total Environ 728: 138764

Ahmed W, Bertsch PM, Bivins A, Bibby K, Farkas K, Gathercole A, Haramoto E, Gyawali P, Korajkic A, McMinn BR, Mueller JF, Simpson SL, Smith WJM, Symonds EM, Thomas KV, Verhagen R, Kitajima M (2020b) Comparison of virus concentration methods for the RT-qPCR-based recovery of murine hepatitis virus, a 
surrogate for SARS-CoV-2 from untreated wastewater. Sci Total Environ 739:139960

Ahmed W, Bertsch PM, Bibby K, Haramoto E, Hewitt J, Huygens F, Gyawali P, Korajkic A, Riddell S, Sherchan SP, Simpson SL, Sirikanchana K, Symonds EM, Verhagen R, Vasan SS, Kitajima M, Bivins A (2020c) Decay of SARS-CoV-2 and surrogate murine hepatitis virus RNA in untreated wastewater to inform application in wastewater-based epidemiology. Environ Res 191:110092

Ahmed W, Bivins A, Bertsch PM, Bibby K, Choi PM, Farkas K, Gyawali P, Hamilton KA, Haramoto E, Kitajima M, Simpson SL, Tandukar S, Thomas K, Mueller JF (2020d) Surveillance of SARS-CoV-2 RNA in wastewater: methods optimisation and quality control are crucial for generating reliable public health information. Curr Opin Environ Sci Health In Press. https://doi.org/10.1016/j.coesh.2020. 09.003

Ajonina C, Buzie C, Ajonina IU, Basner A, Reinhardt H, Gulyas H, Liebau E, Otterpohl R (2012) Occurrence of Cryptosporidium in a wastewater treatment plant in North Germany. J Toxicol Environ Health A 75(22-23):1351-1358

Alhamlan FS, Al-Qahtani AA, Al-Ahdal MN (2015) Recommended advanced techniques for waterborne pathogen detection in developing countries. J Infect Dev Ctries 9(2):128-135

Amirian ES (2020) Potential fecal transmission of SARS-CoV-2: current evidence and implications for public health. Int J Infect Dis 95:363370

Ampuero M, Valenzuela S, Valiente-Echeverría F, Soto-Rifo R, Barriga GP, Chnaiderman J, Rojas C, Guajardo-Leiva S, Díez B, Gaggero A (2020) SARS-CoV-2 detection in sewage in Santiago. Chile - preliminary results medRxiv. https://doi.org/10.1101/2020.07.02. 20145177

Arora S, Nag A, Sethi J, Rajvanshi J, Saxena S, Shrivastava SK, Gupta AB (2020) Sewage surveillance for the presence of SARS-CoV-2 genome as a useful wastewater based epidemiology (WBE) tracking tool in India. medRxiv. https://doi.org/10.1101/2020.06.18. 20135277

Aslan G, Bayram G, Otağ F, Direkel S, Taylan Özkan A, Ceber K, Emekdaş $G$ (2012) Investigation of the presence of Cryptosporidium spp. in different water sources in Mersin province, Turkey. Mikrobiyol Bul 46(1):93-100

Balboa S, Mauricio-Iglesias M, Rodríguez S, Martínez-Lamas L, Vasallo FJ, Regueiro B, Lema JM (2020) The fate of SARS-CoV-2 in wastewater treatment plants points out the sludge line as a suitable spot for incidence monitoring. medRxiv. https://doi.org/10.1101/2020.05. 25.20112706

Bar-Or I, Yaniv K, Shagan M, Ozer E, Erster O, Mendelson E, Mannasse B, Shirazi R, Kramarsky-Winter E, Nir O, Abu-Ali H, Ronen Z, Rinott E, Lewis YE, Friedler E, Bitkover E, Paitan Y, Berchenko Y, Kushmaro A (2020) Regressing SARS-CoV-2 sewage measurements onto COVID-19 burden in the population: a proof-of-concept for quantitative environmental surveillance. medRxiv. https://doi. org/10.1101/2020.04.26.20073569

Ben Ayed L, Yang W, Widmer G, Cama V, Ortega Y, Xiao L (2012) Survey and genetic characterization of wastewater in Tunisia for Cryptosporidium spp., Giardia duodenalis, Enterocytozoon bieneusi, Cyclospora cayetanensis and Eimeria spp. J Water Health 10(3):431-444

Berchenko Y, Manor Y, Freedman LS, Kaliner E, Grotto I, Mendelson E, Huppert A (2017) Estimation of polio infection prevalence from environmental surveillance data. Sci Transl Med 9:eaaf6786

Berglund B, Dienus O, Sokolova E, Berglind E, Matussek A, Pettersson $T$, Lindgren PE (2017) Occurrence and removal efficiency of parasitic protozoa in Swedish wastewater treatment plants. Sci Total Environ 598:821-827

Bertrand I, Ganzter C, Chesnot T, Schwartzbrod J (2004) Improved specificity for Giardia lamblia cyst quantification in wastewater by development of real-time PCR method. J Microbiol Methods 57: $41-53$

Bhatt A, Arora P, Prajapati SK (2020) Occurrence, fates and potential treatment approaches for removal of viruses from wastewater: a review with emphasis on SARS-CoV-2. J Environ Chem Eng 8(5): 104429

Bolland SJ, Zahedi A, Oskam C, Murphy B, Ryan U (2020) Cryptosporidium bollandi n. sp. (Apicomplexa: Cryptosporidiiae) from angelfish (Pterophyllum scalare) and Oscar fish (Astronotus ocellatus). Exp Parasitol 217:107956

Broughton JP, Deng X, Yu G, Fasching CL, Singh J, Streithorst J, Granados A, Sotomayor-Gonzalez A, Zorn K, Gopez A, Hsu E, Gu W, Miller S, Pan CY, Guevara H, Wadford DA, Chen JS, Chiu CY (2020) Rapid detection of 2019 novel coronavirus SARS-CoV-2 using a CRISPR-based DETECTR Lateral Flow Assay. medRxiv. https://doi.org/10.1101/2020.03.06.20032334

Cacciò SM, De Giacomo M, Aulicino FA, Pozio E (2003) Giardia cysts in wastewater treatment plants in Italy. Appl Environ Microbiol 69: 3393-3398

Cacciò SM, Chalmers RM (2016) Human cryptosporidiosis in Europe. Clin Microbiol Infect 22(6):471-480

Campbell AT, Robertson LJ, Snowball MR, Smith HV (1995) Inactivation of oocysts of Cryptosporidium parvum by ultraviolet irradiation. Water Res 29(11):2583-2586

Cao B, Gu AZ, Hong PY, Ivanek R, Li B, Wang A, Wu J (2020) Editorial perspective: viruses in wastewater: wading into the knowns and unknowns. Environ Res In press. https://doi.org/10.1016/j.envres. 2020.110255

Casanova L, Rutala WA, Weber DJ, Sobsey MD (2009) Survival of surrogate coronaviruses in water. Water Res 43:1893-1898

Castiglioni S, Zuccato E, Crisci E, Chiabrando C, Fanelli R, Bagnati R (2006) Identification and measurement of illicit drugs and their metabolites in urban wastewater by liquid chromatography-tandem mass spectrometry. Anal Chem 78(24):8421-8429

Castro-Hermida JA, Garcia-Presedo I, Almeida A, Gonzalez-Warleta M, Correia Da Costa JM, Mezo M (2008) Contribution of treated wastewater to the contamination of recreational river areas with Cryptosporidium spp. and Giardia duodenalis. Water Res 42: $3528-3538$

Castro-Hermida JA, García-Presedo I, Almeida A, González-Warleta M, Correia Da Costa JM, Mezo M (2011) Cryptosporidium spp. and Giardia duodenalis in two areas of Galicia (NW Spain). Sci Total Environ 409(13):2451-2459

Cacció SM, Sprong H (2014) Epidemiology of giardiasis in humans. In: Lujan HD, Svard S (eds) Giardia: A model organism. Springer, Vienna, New York, pp 16-28

Cesewski E, Johnson BN (2020) Electrochemical biosensors for pathogen detection. Biosens Bioelectron 159:112214

CDC (2020) 2019-Novel Coronavirus (2019-nCoV) Real-Time rRTPCR panel primers and probes. U.S. Centers for Disease Control and Prevention, https://www.cdc.gov/coronavirus/2019-ncov/lab/rtpcr-panel-primer-probes.html Accessed October $21^{\text {st }} 2020$

Chappell CL, Okhuysen PC, Sterling CR, DuPont HL (1996) Cryptosporidium parvum: intensity of infection and oocyst excretion patterns in healthy volunteers. J Infect Dis 173(1):232-236

Chappell CL, Okhuysen PC, Langer-Curry R, Widmer G, Akiyoshi DE, Tanriverdi S, Tzipori S (2006) Cryptosporidium hominis: experimental challenge of healthy adults. Am J Trop Med Hyg 75(5): $851-857$

Chavarria-Miró G, Anfruns-Estrada E, Guix S, Paraira M, Galofré B, Sáanchez G (2020) Sentinel surveillance of SARS-CoV-2 in wastewater anticipates the occurrence of COVID-19 cases. medRxiv. https://doi.org/10.1101/2020.06.13.20129627

Cheung KS, Hung IFN, Chan PPY, Lung KC, Tso E, Liu R, Ng YY, Chu MY, Chung TWH, Tam AR, Yip CCY, Leung KH, Fung AY, Zhang RR, Lin Y, Cheng HM, Zhang AJX, To KKW, Chan KH, 
Yuen KY, Leung WK (2020) Gastrointestinal manifestations of SARS-CoV-2 infection and virus load in fecal samples from a Hong Kong cohort: systematic review and meta-analysis. Gastroenterol 159(1):81-95

Choi PM, Tscharke BJ, Donner E, O'Brien JW, Grant SC, Kaserzon SL (2018) Wastewater-based epidemiology biomarkers: past, present and future. TrAC Trends in Anal Chem 105:453-469

Coffey CM, Collier SA, Gleason ME, Yoder JS, Kirk MD, Richardson AM, Fullerton KE, Benedict KM (2020). Clin Infect Di 12:ciaa128. https://doi.org/10.1093/cid/ciaa128

Corman VM, Landt O, Kaiser M, Molenkamp R, Meijer A, Chu DK, Bleicker T, Brünink S, Schneider J, Schmidt ML, Mulders DG, Haagmans BL, van der Veer B, van den Brink S, Wijsman L, Goderski G, Romette JL, Ellis J, Zambon M, Peiris M, Goossens H, Reusken C, Koopmans MP, Drosten C (2020) Detection of 2019 novel coronavirus $(2019-\mathrm{nCoV})$ by real-time RT-PCR. Euro Surveill 25(3):2000045

Curtis T (2003) 30 - Bacterial pathogen removal in wastewater treatment plants. In: Mara D, Horn N (eds): Handbook of Water and Wastewater Microbiology, Academic Press, pp 477-449

Danciger M, Lopez M (1975) Numbers of Giardia in the feces of infected children. Am J Trop Med Hyg 24(2):237-242

Daughton CG (2020) Wastewater surveillance for population-wide Covid-19: the present and future. Sci Total Environ 736:139631

Deere D, Khan S (2016) Collation and analysis of source water pathogen monitoring data. Water Research Australia for WaterVal for the Australian Water Recycling Centre of Excellence. https://www. waterra.com.au/research/waterval/

Deere D, Sobsey M, Sinclair M, Hill K and White P (2020) Historical context and initial expectations on sewage surveillance to inform the control of COVID-19. HealthStream, Issue 97, Water Research Australia

Deng X, Gu W, Federman S, du Plessis L, Pybus OG, Faria NR, Wang C, Yu G, Bushnell B, Pan CY, Guevara H, Sotomayor-Gonzalez A, Zorn K, Gopez A, Servellita V, Hsu E, Miller S, Bedford T, Greninger AL, Roychoudhury P, Starita LM, Famulare M, Chu HY, Shendure J, Jerome KR, Anderson C, Gangavarapu K, Zeller M, Spencer E, Andersen KG, MacCannell D, Paden CR, Li Y, Zhang J, Tong S, Armstrong G, Morrow S, Willis M, Matyas BT, Mase S, Kasirye O, Park M, Masinde G, Chan C, Yu AT, Chai SJ, Villarino E, Bonin B, Wadford DA, Chiu CY (2020) Genomic surveillance reveals multiple introductions of SARS-CoV-2 into northern California. Science 369(6503):582-587

Dong S, Yang Y, Wang Y, Yang D, Yang Y, Shi Y, Li C, Li L, Chen Y, Jiang Q, Zhou Y (2020) Prevalence of Cryptosporidium infection in the global population: a systematic review and meta-analysis. Acta Parasitol 65(4):882-889

Dunn N, Juergens AL (2020) Giardiasis. In: StatPearls. Treasure Island (FL): StatPearls publishing; 2020 Jan-. Available from: https:// www.ncbi.nlm.nih.gov/books/NBK513239/

DuPont HL, Chappell CL, Sterling CR, Okhuysen PC, Rose JB, Jakubowski W (1995) The infectivity of Cryptosporidium parvum in healthy volunteers. N Engl J Med 332(13):855-859

Eden JS, Rockett R, Carter I, Rahman H, de Ligt J, Hadfield J, Storey M, Ren X, Tulloch R, Basile K, Wells J, Byun R, Gilroy N, O'Sullivan MV, Sintchenko V, Chen SC, Maddocks S, Sorrell TC, Holmes EC, Dwyer DE, Kok J; 2019-nCoV Study Group (2020) An emergent clade of SARS-CoV-2 linked to returned travellers from Iran. Virus Evol 6(1):veaa027

Efstratiou A, Ongerth JE, Karanis P (2017) Waterborne transmission of protozoan parasites: review of worldwide outbreaks - an update 2011-2016. Water Res 114:14-22

Emelko MB (2003) Removal of viable and inactivated Cryptosporidium by dual-and tri-media filtration. Water Res 37:2998-3008

Farkas K, Hillary LS, Malham SK, McDonald JE, Jones DL (2020) Wastewater and public health: the potential of wastewater surveillance for monitoring COVID-19. Curr Opin Environ Sci Health 17:14-20

Feng Y, Li N, Duan L, Xiao L (2009) Cryptosporidium genotype and subtype distribution in raw wastewater in Shanghai, China: evidence for possible unique Cryptosporidium hominis transmission. J Clin Microbiol 47(1): 153-157

Feng Y, Ryan UM, Xiao L (2018) Genetic diversity and population structure of Cryptosporidium. Trends Parasitol 34:997-1011

Ferrer A, Nguyen-Viet H, Zinsstag J (2012) Quantification of diarrhea risk related to wastewater contact in Thailand. Ecohealth 29(1):49 59

Foladori P, Cutrupi F, Segata N, Manara S, Pinto F, Malpei F, Bruni L, La Rosa G (2020) SARS-CoV-2 from faeces to wastewater treatment: what do we know? A review. Sci Total Environ 743:140444

Fongaro G, Stoco PH, Sobral Marques Souza D, Grisars EC, Magri ME, Rogovski P, Schörner AM, Barazzetti FH, Christoff AP, de Oliveira L F V, Bazzo ML, Wagner G, Hernández M, Rodriguez-Lázaro D (2020) SARS-CoV-2 in human sewage in Santa Catalina, Brazil, November 2019. medRxiv. https://doi.org/10.1101/2020.06.26. 20140731

Fu C, Xie X, Huang JJ, Zhang T, Wu QY, Chen JN, Hu HY (2010) Monitoring and evaluation of removal of pathogens at municipal wastewater treatment plants. Water Sci Technol 61:1589-1599

Funari R, Chu KY, Shen AQ (2020) Detection of antibodies against SARS-CoV-2 spike protein by gold nanospikes in an optomicrofluidic chip. Biosens Bioelectron 169:112578

Gallas-Lindemann C, Sotiriadou I, Plutzer J, Karanis P (2013) Prevalence and distribution of Cryptosporidium and Giardia in wastewater and the surface, drinking and ground waters in the lower Rhine, Germany. Epidemiol Infect 141(1):9-21

Gennaccaro AL, McLaughlin MR. Quintero-Betancourt W, Huffman DE, Rose JB (2003). Infectious Cryptosporidium parvum oocysts in final reclaimed effluent. Appl Environ Microbiol 69(8):49834984

Giangaspero A, Cirillo R, Lacasella V, Lonigro A, Marangi M, Cavallo P, Berrilli F, Di Cave D, Brandonisio O (2009) Giardia and Cryptosporidium in inflowing water and harvested shellfish in a lagoon in southern Italy. Parasitol Int 58(1):12-17

Gleick PH (2002) Dirty-water: estimated deaths from water-related diseases 2000-2020. Oakland, CA: Pacific Institute for Studies in Development, Environment, and Security. https://pacinst.org/ publication/569/ Accessed October 2020

Gómez-Couso H, Méndez-Hermida F, Castro-Hermida JA, Ares-Mazás E (2006) Cryptosporidium contamination in harvesting areas of bivalve molluscs. J Food Prot 69(1):185-190

Gonzalez R, Curtis K, Bivins A, Bibby K, Weir MH, Yetka K, Thompson H, Keeling D, Mitchell J, Gonzalez D (2020) COVID-19 surveillance in southeastern Virginia using wastewater-based epidemiology. Water Res 186:116296

Green H, Wilder M, Collins M, Fenty A, Gentile K, Brittany L, Zeng T, Middleton FA, Larsen DA (2020) Quantification of SARS-CoV-2 and cross-assembly phage (crAssphage) from wastewater to monitor coronavirus transmission within communities. medRxiv. https://doi. org/10.1101/2020.05.21.20109181

Gundy PM, Gerba CP, Pepper IL (2009) Survival of coronaviruses in water and wastewater. Food Environ Virol 1:10

Guy RA, Payment P, Krull UJ, Horgen PA (2003) Real-time PCR for quantification of Giardia and Cryptosporidium in environmental water samples and wastewater. Appl Environ Microbiol 69:51785185

Hall GV, Kirk MD, Ashbolt R, Stafford R, Lalor K, Group OW (2006) Frequency of infectious gastrointestinal illness in Australia, 2002: regional, seasonal and demographic variation. Epidemiol Infect 134: $111-118$

Hamilton KA, Waso M, Reyneke B, Saeidi N, Levine A, Lalancette C, Besner MC, Khan W, Ahmed W (2018) Cryptosporidium and 
Giardia in wastewater and surface water environments. J Environ Qual 47(5):1006-1023

Hanevik K, Hausken T, Morken MH, Strand EA, Mørch K, Coll P, Helgeland L, Langeland N (2007) Persisting symptoms and duodenal inflammation related to Giardia duodenalis infection. J Inf Secur 55(6):524-530

Hänninen ML, Horman A, Rimhanen-Finne R, Vahtera H, Malmberg S, Herve S, Lahti K (2005) Monitoring of Cryptosporidium and Giardia in the Vantaa river basin, southern Finland. Int J Hyg Environ Health 208:163-171

Haramoto E, Malla B, Thakali O, Kitajima M (2020) First environmental surveillance for the presence of SARS-CoV-2 RNA in wastewater and river water in Japan. Sci Total Environ 737:140405

Hart OE, Halden RU (2020) Computational analysis of SARS-CoV-2/ COVID-19 surveillance by wastewater-based epidemiology locally and globally: feasibility, economy, opportunities and challenges. Sci Total Environ 730:138875

Hashimoto A, Sugimoto H, Morita S, Hirata T (2006) Genotyping of single Cryptosporidium oocysts in sewage by semi-nested PCR and direct sequencing. Water Res 40:2527-2532

Hata A, Honda R, Hara-Yamamura H, Meuchi Y (2020) Detection of SARS-CoV-2 in wastewater in Japan during a COVID-19 outbreak. Sci Total Environ 2020:143578. https://doi.org/10.1016/j.scitotenv. 2020.143578

Hatam-Nahavandi K, Mohebali M, Mahvi AH, Keshavarz H, Najafian HR, Mirjalali H, Rezaei S, Rezaeian M (2016) Microscopic and molecular detection of Cryptosporidium andersoni and Cryptosporidium xiaoi in wastewater samples of Tehran province, Iran. Iran J Parasitol 11:499-506

Hatam-Nahavandi K, Mohebali M, Mahvi AH, Keshavarz H, Mirjalali H, Rezaei S, Meamar AR, Rezaeian M (2017) Subtype analysis of Giardia duodenalis isolates from municipal and domestic raw wastewaters in Iran. Environ Sci Pollut Res Int 4(14):12740-12747

Heaton KW, Radvan J, Cripps H, Mountford RA, Braddon FE, Hughes AO (1992) Defecation frequency and timing, and stool form in the general population: a prospective study. Gut 33:818-824

Hirata T, Hashimoto A (2006) Genotyping of single Cryptosporidium oocysts isolated from sewage and river water. Water Sci Technol 54:197-202

Holshue ML, DeBolt C, Lindquist S (2020) First case of 2019 novel coronavirus in the United States. N Engl J Med 382:929-936

Holubová N, Tůmová L, Sak B, Hejzlarová A, Konečný R, McEvoy J, Kváč M (2020) Description of Cryptosporidium ornithophilus n. sp. (Apicomplexa Cryptosporidiidae) in farmed ostriches. Parasit Vectors 13:340

Huang C, Hu Y, Wang L, Wang Y, Li N, Guo Y, Feng Y, Xiao L (2017) Environmental transport of emerging human-pathogenic Cryptosporidium species and subtypes through combined sewer overflow and wastewater. Appl Environ Microbiol 83:e00682$\mathrm{e} 00617$

Huang Z, Tian D, Liu Y, Lin Z, Lyon C, Lai W, Fusco D, Drouin A, Yin $X, \mathrm{Hu} T$, Ning B (2020) Ultra-sensitive and high-throughput CRISPR-powered COVID-19 diagnosis. Biosens Bioelectron 164: 112316

Imre K, Morar A, Ilie MS, Plutzer J, Imre M, Emil T, Herbei MV, Dărăbus G (2017) Survey of the occurrence and human infective potential of Giardia duodenalis and Cryptosporidium spp. in wastewater and different surface water sources of Western Romania. Vector Borne Zoonotic Dis 17:685-691

Jakubowski W, Sykora JL, Sorber CA, Casson LW, Gavaghan PD (1991) Determining Giardiasis prevalence by examination of sewage. Wat Sci Tech 24:173-178

Ježková J, Prediger J, Holubová N, Sak B, Konečný R, Feng Y, Xiao L, Rost M, McEvoy J, Kváč M (2020) Cryptosporidium ratti n. sp. (Apicomplexa: Cryptosporidiidae) and genetic diversity of
Cryptosporidium spp. in brown rats (Rattus norvegicus) in the Czech Republic. Parasitol 28:1-14

Jiang W, Roellig DM, Li N, Wang L, Guo Y, Feng Y, Xiao L (2020) Contribution of hospitals to the occurrence of enteric protists in urban wastewater. Parasitol Res 119(9):3033-3040

Jokipii L, Jokipii AM (1986) Timing of symptoms and oocyst excretion in human cryptosporidiosis. New Engl J Med 315:643-647

Khalil IA, Troeger C, Rao PC, Blacker BF, Brown A, Brewer TG, Colombara DV, De Hostos EL, Engmann C, Guerrant RL, Haque R, Houpt ER, Kang G, Korpe PS, Kotloff KL, Lima AAM, Petri WA Jr, Platts-Mills JA, Shoultz DA, Forouzanfar MH, Hay SI, Reiner RC Jr, Mokdad AH (2018) Morbidity, mortality, and longterm consequences associated with diarrhoea from Cryptosporidium infection in children younger than 5 years: a meta-analyses study. Lancet Glob Health 6:e758-e768

Khouja LB, Cama V, Xiao L (2010) Parasitic contamination in wastewater and sludge samples in Tunisia using three different detection techniques. Parasitol Res 107(1):109-116

King B, Fanok S, Phillips R, Swaffer B, Monis P (2015a) Integrated Cryptosporidium assay to determine oocyst density, infectivity, and genotype for risk assessment of source and reuse water. Appl Environ Microbiol 81(10):3471-3481

King B, Fanok S, Phillips R, Lau M, van den Akker B, Monis P (2015b) Inactivation of Cryptosporidium across the wastewater treatment train: recycled water fit for purpose. (Phase II). Smart Water Fund project $80 \mathrm{~S}-8012$. https://waterportal.com.au/swf/images/swf-files/ 8os-8012-wra-final-smart-water-fund-report.pdf Accessed October 2020

King B, Fanok S, Phillips R, Lau M, van den Akker B, Monis P (2017) Cryptosporidium attenuation across the wastewater treatment train: recycled water fit for purpose. Appl Environ Microbiol 83(5): e03068-e03016

Kirby AE, Streby A, Moe CL (2016) Vomiting as a symptom and transmission risk in Norovirus illness: evidence from human challenge studies. PLoS One 11(4):e0143759

Kitajima M, Haramoto E, Iker BC, Gerba CP (2014) Occurrence of Cryptosporidium, Giardia, and Cyclospora in influent and effluent water at wastewater treatment plants in Arizona. Sci Total Environ 484:129-136

Kitajima M, Ahmed W, Bibby K, Carducci A, Gerba CP, Hamilton KA, Haramoto E, Rose JB (2020) SARS-CoV-2 in wastewater: state of the knowledge and research needs. Sci Total Environ 739:139076

Kocamemi BA, Kurt H, Hacio S, Yaral C, Saatci AM, Pakdemirli B (2020) First data-set on SARS-CoV-2 detection for Istanbul wastewaters in Turkey. medRxiv. https://doi.org/10.1101/2020.05.03. 20089417

Kumar M, Patel AK, Shah AV, Rava J, Rajpara N, Joshi M, Joshi CG (2020) First proof of the capability of wastewater surveillance for COVID-19 in India through detection of genetic material of SARSCoV-2. Sci Total Environ 746:141326

La Marca A, Capuzzo M, Paglia T, Roli L, Trenti T, Nelson SM (2020) Testing for SARS-cov-2 (COVID-19): a systematic review and clinical guide to molecular and serological in-vitro diagnostic assays. Reproductive BioMed 41(3):483-499

La Rosa G, Iaconelli M, Mancini P, Bonanno Ferraro G, Veneri C, Bonadonna L, Lucentini L, Suffredini E (2020a) First detection of SARS-CoV-2 in untreated wastewaters in Italy. Sci Total Environ 736:139652

La Rosa G, Mancini P, Bonanno FG, Veneri C, Iaconelli M, Bonadonna L, Lucentini L, Suffredini E (2020b) SARS-CoV-2 has been circulating in northern Italy since December 2019: evidence from environmental monitoring. Sci Total Environ 750:141711

Lescure FX, Bouadma L, Nguyen D, Parisey M, Wicky PH, Behillil S, Gaymard A, Bouscambert-Duchamp M, Donati F, Le Hingrat Q, Enouf V, Houhou-Fidouh N, Valette M, Mailles A, Lucet JC, Mentre F, Duval X, Descamps D, Malvy D, Timsit JF, Lina B, 
van-der-Werf S, Yazdanpanah Y (2020) Clinical and virological data of the first cases of COVID-19 in Europe: a case series. Lancet Infect Dis 20(6):697-706

Li N, Xiao L, Wang L, Zhao S, Zhao X, Duan L, Guo M, Liu L, Feng Y (2012) Molecular surveillance of Cryptosporidium spp., Giardia duodenalis, and Enterocytozoon bieneusi by genotyping and subtyping parasites in wastewater. PLoS Negl Trop Dis 6(9):e1809

Li X, Harwood VJ, Nayak B, Staley C, Sadowsky MJ, Weidhaas J (2015) A novel microbial source tracking microarray for pathogen detection and fecal source identification in environmental systems. Environ Sci Technol 49(12):7319-7329

Liu A, Ji H, Wang E, Liu J, Xiao L, Shen Y, Li Y, Zhang W, Ling H (2011) Molecular identification and distribution of Cryptosporidium and Giardia duodenalis in raw urban wastewater in Harbin, China. Parasitol Res 109(3):913-918

Lodder W, de Roda Husman AM (2020) SARS-CoV-2 in wastewater: potential health risk, but also data source. Lancet Gastroenterol Hepatol 5:533-534

Lonigro A, Pollice A, Spinelli R, Berrilli F, Di Cave D, D'Orazi C, Cavallo P, Brandonisio O (2006) Giardia cysts and Cryptosporidium oocysts in membrane-filtered municipal wastewater used for irrigation. Appl Environ Microbiol 72(12):7916-7918

Lu D, Huang Z, Luo J, Zhang X, Sha S (2020) Primary concentration the critical step in implementing the wastewater-based epidemiology for the COVID-19 pandemic: a mini-review. Sci Total Environ 747: 141245

Luka G, Samiei E, Dehghani S, Johnson T, Najjaran H, Hoorfar M (2019) Label-free capacitive biosensor for detection of Cryptosporidium. Sensors 19(2):258

Ma J, Feng Y, Hu Y, Villegas EN, Xiao L (2016) Human infective potential of Cryptosporidium spp., Giardia duodenalis and Enterocytozoon bieneusi in urban wastewater treatment plant effluents. J Water Health 14:411-423

Ma L, Zhang X, Jian Y, Li X, Wang G, Hu Y, Karanis P (2019) Detection of Cryptosporidium and Giardia in the slaughterhouse, sewage and river waters of the Qinghai Tibetan plateau area (QTPA), China. Parasitol Res 118:2041-2051

MacKenzie WR, Hoxie NJ, Proctor ME, Gradus MS, Blair KA, Peterson DE, Kazmierczak JJ, Addiss DG, Fox KR, Rose JB (1994) A massive outbreak in Milwaukee of Cryptosporidium infection transmitted through the public water supply. N Engl J Med 331(3):161-167

Mandal P, Gupta AK, Dubey BK (2020) A review on presence, survival, disinfection/removal methods of coronavirus in wastewater and progress of wastewater-based epidemiology. J Environ Chem Eng 8(5): 104317

Mao K, Zhang K, Du W, Ali W, Feng X, Zhang H (2020a) The potential of wastewater-based epidemiology as surveillance and early warning of infectious disease outbreaks. Curr Opin Environ Sci Health $17: 1-7$

Mao K, Zhang H, Zhugen Y (2020b) Can a paper-based device trace COVID-19 sources with wastewater-based epidemiology? Environ Sci Technol 54(7):3733-3735

Mao K, Zhang H, Zhugen Y (2020c) An integrated biosensor system with mobile health and wastewater-based epidemiology (iBMW) for COVID-19 pandemic. Biosens Bioelectron 169:112617

Martin J, Klapsa D, Wilton T, Zambon M, Bentley E, Bujaki E, Fritzsche M, Mate R, Majumdar M (2020) Tracking SARS-CoV-2 in sewage: evidence of changes in virus variant predominance during COVID19 pandemic. Viruses 12(10):E1144

Martins FDC, Ladeia WA, Toledo RDS, Garcia JL, Navarro IT, Freire RL (2019) Surveillance of Giardia and Cryptosporidium in sewage from an urban area in Brazil. Rev Bras Parasitol Vet 28:291-297

Más Lago P, Gary HE Jr, Pérez LS, Cáceres V, Olivera JB, Puentes RP, Corredor MB, Jímenez P, Pallansch MA, Cruz RG (2003) Poliovirus detection in wastewater and stools following an immunization campaign in Havana, Cuba. Int J Epidemiol 32(5):772-777
Mavrikou S, Moschopoulou G, Tsekouras V, Kintzios S (2020) Development of a portable, ultra-rapid and ultra-sensitive cell-based biosensor for the direct detection of the SARS-CoV-2 S1 spike protein antigen. Sensors 20(11):3121

Mayer CL, Palmer CJ (1996) Evaluation of PCR, nested PCR, and fluorescent antibodies for detection of Giardia and Cryptosporidium species in wastewater. Appl Environ Microbiol 62:2081-2085

McLellan N, Pernitsky D, Umble A (2020). Coronavirus and the water cycle - here is what treatment professionals need to know, Available at:https:/www.wateronline.com/doc/coronavirus-andthe-water-cycle-here-is-what-treatment-professionals-need-toknow-0001 Accessed November $16^{\text {th }} 2020$

Medema G, Heijnen L, Elsinga G, Italiaander R, Brouwer A (2020) Presence of SARS-coronavirus-2 RNA in sewage and correlation with reported COVID-19 prevalence in the early stage of the epidemic in the Netherlands. Environ Sci Technol Lett 7:511-516

Michael-Kordatou I, Karaolia P, Fatta-Kassinos D (2020) Sewage analysis as a tool for the COVID-19 pandemic response and management: the urgent need for optimised protocols for SARS-CoV-2 detection and quantification. J Environ Chem Eng 8:104306

Mlejnkova H, Sovova K, Vasickova P, Ocenaskova V, Jasikova L, Juranova E (2020) Preliminary study of Sars-Cov-2 occurrence in wastewater in the Czech Republic. Int J Environ Res Public Health 17:5508

Moore C, Nokes Ch, Loe B, Close M, Pang L, Smith V, Osbaldiston S (2010) Guidelines for separation distances based on virus transport between on-site domestic wastewater systems and wells. Environmental Science and Research Limited Client Report No. CSC1001. New Zealand Accessed November $16^{\text {th }} 2020$

Nasser AM, Vaizel-Ohayon D, Aharoni A, Revhun M (2012) Prevalence and fate of Giardia cysts in wastewater treatment plants. J Appl Microbiol 113(3):477-484

Nasser AM (2016) Removal of Cryptosporidium by wastewater treatment processes: a review. J Water Health 14(1):1-13

Nemudryi A, Nemudraia A, Wiegand T, Surya K, Buyukyoruk M, Cicha C, Vanderwood KK, Wilkinson R, Wiedenheft B (2020) Temporal detection and phylogenetic assessment of SARS-CoV-2 in municipal wastewater. Cell Rep Med 1(6):100098

Oda T, Kawabata M, Uga S (2005) Detection of Giardia cysts in sewage and estimations of Giardiasis prevalence among inhabitants in Hyogo prefecture, Japan. Trop Med Health 33:1-5

Oreshkova N, Molenaar RJ, Vreman S, Harders F, Oude Munnink BB, Hakze-van der Honing RW, Gerhards N, Tolsma P, Bouwstra R, Sikkema RS, Tacken MG, de Rooij MM, Weesendorp E, Engelsma MY, Bruschke CJ, Smit LA, Koopmans M, van der Poel WH, Stegeman A (2020) SARS-CoV-2 infection in farmed minks, the Netherlands, April and May 2020. Euro Surveill 25(23):2001005

Pan Y, Zhang D, Yang P, Poon LLM, Wang Q (2020) Viral load of SARS-CoV-2 in clinical samples. Lancet Infect Dis 20(4):411-412

Peccia J, Zulli A, Brackney DE, Grubaugh ND, Kaplan EH, CasanovasMassana A, Ko AI, Malik AA, Wang D, Wang M, Warren JL, Weinberger DM, Arnold W, Omer SB (2020) Measurement of SARS-CoV-2 RNA in wastewater tracks community infection dynamics. Nat Biotechnol 38(10):1164-1167

Peiris JS, Chu CM, Cheng VC, Chan KS, Hung IF, Poon LL, Law KI, Tang BS, Hon TY, Chan CS, Chan KH, Ng JS, Zheng BJ, Ng WL, Lai RW, Guan Y, Yuen KY, HKU/UCH SARS Study Group (2003) Clinical progression and viral load in a community outbreak of coronavirus-associated SARS pneumonia: a prospective study. Lancet 361(9371):1767-1772

Pöyry T, Stenvik M, Hovi T (1988) Viruses in sewage waters during and after a poliomyelitis outbreak and subsequent nationwide oral poliovirus vaccination campaign in Finland. Appl Environ Microbiol 54: $371-374$

Prado T, Fumian TM, Mannarino CF, Maranhão AG, Siqueira MM, Miagostovich MP (2020) Preliminary results of SARS-CoV-2 
detection in sewerage system in Niterói municipality, Rio de Janeiro, Brazil. Mem Inst Oswaldo Cruz 115:e200196

Qiu G, Gai Z, Tao Y, Schmitt J, Kullak-Ublick GA, Wang J (2020) Dualfunctional plasmonic photothermal biosensors for highly accurate severe acute respiratory syndrome coronavirus 2 detection. ACS Nano 14(5):5268-5277

Quintero-Betancourt W, Gennaccaro AL, Scott TM, Rose JB (2003) Assessment of methods for detection of infectious Cryptosporidium oocysts and Giardia cysts in reclaimed effluents. Appl Environ Microbiol 69(9):5380-5388

Ramírez-Castillo FY, Loera-Muro A, Jacques M, Garneau P, AvelarGonzález FJ, Harel J, Guerrero-Barrera AL (2015) Waterborne pathogens: detection methods and challenges. Pathogens 4(2):307-334

Ramo A, Del Cacho E, Sánchez-Acedo C, Quílez J (2017) Occurrence and genetic diversity of Cryptosporidium and Giardia in urban wastewater treatment plants in north-eastern Spain. Sci Total Environ 598:628-638

Randazzo W, Cuevas-Ferrando E, Sanjuán R, Domingo-Calap P, Sánchez G (2020a) Metropolitan wastewater analysis for COVID19 epidemiological surveillance. Int J Hyg Environ Health 230: 113621

Randazzo W, Truchado P, Cuevas-Ferrando E, Simón P, Allende A, Sánchez G (2020b) SARS-CoV-2 RNA in wastewater anticipated COVID-19 occurrence in a low prevalence area. Water Res 181: 115942

Razzolini MTP, Breternitz BS, Kuchkarian B, Bastos VK (2020) Cryptosporidium and Giardia in urban wastewater: a challenge to overcome. Environ Pollut 257:113545

Regli S, Rose JB, Hass C, Gerba C (1991) Modeling the risk from Giardia and viruses in drinking water. J Am Water Works Assoc 83:76-84

Rendtorff RC (1954) The experimental transmission of human intestinal protozoan parasites. II. Giardia lamblia cysts given in capsules. Am J Hyg 59:209-220

Rendtorff RC (1979) The experimental transmission of Giardia lamblia among volunteer subjects. In: Jakubowski, W., Hoff, J.C. (eds) Waterborne transmission of giardiasis. EPA-600/9-79-001. U.S. Environmental Protection Agency, Cincinnati, OH, pp. 64-81

Rimoldi SG, Stefani F, Gigantiello A, Polesello S, Comandatore F, Mileto D, Maresca M, Longobardi C, Mancon A, Romeri F, Pagani C, Cappelli F, Roscioli C, Moja L, Gismondo MR, Salerno F (2020) Presence and infectivity of SARS-CoV-2 virus in wastewaters and rivers. Sci Total Environ 744:140911

Robertson LJ, Forberg T, Hermansen L, Gjerde BK, Alvsvåg JO, Langeland N (2006) Cryptosporidium parvum infections in Bergen, Norway, during an extensive outbreak of waterborne giardiasis in autumn and winter 2004. Appl Environ Microbiol 72(3): 2218-2220

Rockett RJ, Arnott A, Lam C, Sadsad R, Timms V, Gray KA, Eden JS, Chang S, Gall M, Draper J, Sim EM, Bachmann NL, Carter I, Basile K, Byun R, O'Sullivan MV, Chen SC, Maddocks S, Sorrell TC, Dwyer DE, Holmes EC, Kok J, Prokopenko M, Sintchenko V (2020) Revealing COVID-19 transmission in Australia by SARS$\mathrm{CoV}-2$ genome sequencing and agent-based modeling. Nat Med 26(9):1398-1404

Ryan U, Paparini A, Oskam C (2017) New technologies for detection of enteric parasites. Trends Parasitol 33(7):532-546

Ryan U, Zahedi A (2019) Molecular epidemiology of giardiasis from a veterinary perspective. Adv Parasitol 106:209-254

Samie A, Ntekele P (2014) Genotypic detection and evaluation of the removal efficiency of Giardia duodenalis at municipal wastewater treatment plants in northern South Africa. Trop Biomed 31(1):122133

Sammarro Silva KJ, Sabogal-Paz LP (2020) Cryptosporidium spp. and Giardia spp. (oo)cysts as target-organisms in sanitation and environmental monitoring: a review in microscopy-based viability assays. Water Res 189:116590

Schijven J, Hassanizadeh S (2000) Removal of virus by soil passage: overview of modeling, processes and parameters. Crit Rev Environ Sci Technol 30:49-127

Schijven J, Mulschegel JHC, Hassanizadeh M, Teunis PFM, de Roda Husman AM (2006) Determination of protection zones for Dutch groundwater wells against virus contamination-uncertainty and sensitivity analysis. J Water Health 4:297-312

Schmitz BW, Moriyama H, Haramoto E, Kitajima M, Sherchan S, Gerba CP, Pepper IL (2018) Reduction of Cryptosporidium, Giardia, and fecal indicators by Bardenpho wastewater treatment. Environ Sci Technol 52(12):7015-7023

Schoeman D, Fielding BC (2019) Coronavirus envelope protein: current knowledge. Virol J 16:69

Seo G, Lee G, Kim MJ, Baek SH, Choi M, Ku KB, Lee CS, Jun S, Park D, Kim HG, Kim SJ, Lee JO, Kim BT, Park EC, Kim SI (2020) Rapid detection of COVID-19 causative virus (SARS-CoV-2) in human nasopharyngeal swab specimens using field-effect transistor-based biosensor. ACS Nano 14(4):5135-5142

Sharif S, Ikram A, Khurshid A, Salman M, Mehmood N, Arshad Y, Ahmad J, Angez M, Alam MM, Rehman L, Mujtaba G (2020) Detection of SARS-Coronavirus-2 in wastewater, using the existing environmental surveillance network: an epidemiological gateway to an early warning for COVID-19 in communities. medRxiv. https:// doi.org/10.1101/2020.06.03.20121426

Sherchan SP, Shahin S, Ward LM, Tandukar S, Aw TG, Schmitz B, Ahmed W, Kitajima M (2020) First detection of SARS-CoV-2 RNA in wastewater in North America: a study in Louisiana, USA. Sci Total Environ 743:140621. https://doi.org/10.1016/j.scitotenv. 2020.140621

Shirley DT, Moonah SN, Kotloff KL (2012) Burden of disease from cryptosporidiosis. Curr Opin Infect Dis 25(5):555-563

Silverman JD, Hupert N, Washburne AD (2020) Using influenza surveillance networks to estimate state-specific prevalence of SARS-CoV2 in the United States. Sci Transl Med 12:eabc1126

Sims N, Kasprzyk-Hordern B (2020) Future perspectives of wastewaterbased epidemiology: monitoring infectious disease spread and resistance to the community level. Environ Int 139:105689

Soller JA, Eftim SE, Warren I, Nappier SP (2017) Evaluation of microbiological risks associated with direct potable reuse. Microb Risk Anal 5:3-14

Spanakos G, Biba A, Mavridou A, Karanis P (2015) Occurrence of Cryptosporidium and Giardia in recycled waters used for irrigation and first description of Cryptosporidium parvum and C. muris in Greece. Parasitol Res 114:1803-1310

Stehr-Green JK, McCaig L, Remsen HM, Rains CS, Fox M, Juranek DD (1987) Shedding of oocysts in immunocompetent individuals infected with Cryptosporidium. Am J Trop Med Hyg 36(2):338-342

Sulaiman IM, Jiang J, Singh A, Xiao L (2004) Distribution of Giardia duodenalis genotypes and subgenotypes in raw urban wastewater in Milwaukee, Wisconsin. Appl Environ Microbiol 70:3776-3780

Swaffer BA, Vial HM, King BJ, Daly R, Frizenschaf J, Monis PT (2014) Investigating source water Cryptosporidium concentration, species and infectivity rates during rainfall-runoff in a multi-use catchment. Water Res 67:310-320

Tang A, Tong ZD, Wang HL, Dai YX, Li KF, Liu JN, Wu WJ, Yuan C, Yu ML, Li P, Yan JB (2020) Detection of novel coronavirus by RTPCR in stool specimen from asymptomatic child, China. Emerg Infect Dis 26(6): 1337-1339

Taran-Benshoshan M, Ofer N, Dalit VO, Aharoni A, Revhun M, Nitzan Y, Nasser AM (2015) Cryptosporidium and Giardia removal by secondary and tertiary wastewater treatment. J Environ Sci Health A Tox Hazard Subst Environ Eng 50(12):1265-1273

Troeger C, Blacker BF, Khalil IA, Rao PC, Cao S, Zimsen SRM, Albertson S, Stanaway JD, Deshpande A, Brown A, Abebe Z, 
Alvis-Guzman N, Amare AT et al (2018) Estimates of the global, regional, and national morbidity, mortality, and aetiologies of diarrhoea in 195 countries: a systematic analysis for the Global Burden of Disease Study 2016. Lancet Infect Dis 18(11):1211-1228

Trottier J, Darques R, Ait Mouheb N, Partiot E, Bakhache W, Deffieu MS, Gaudin R (2020) Post-lockdown detection of SARS-CoV-2 RNA in the wastewater of Montpellier, France. One Health 10: 100157

Tsuchihashi R, Loge FJ, Darby JL (2003) Detection of Cryptosporidium parvum in secondary effluents using a most probable numberpolymerase chain reaction assay. Water Environ Res 75(4):292-299

Ulloa-Stanojlović FM, Aguiar B, Jara LM, Sato MI, Guerrero JA, Hachich E, Matté GR, Dropa M, Matté MH, de Araújo RS (2016) Occurrence of Giardia intestinalis and Cryptosporidium sp. in wastewater samples from São Paulo state, Brazil, and Lima, Peru. Environ Sci Pollut Res Int 23(21):22197-22205

UN (2017) The United Nations world water development report, 2017: Wastewater: the untapped resource. https://unesdoc.unesco.org/ark:/ 48223/pf0000247153?posInSet=5\&queryId=N-EXPLORE7383672f-bf39-4492-bdc3-40e064191d3f. Accessed November $16^{\text {th }} 2020$

USEPA (2014) United States Environmental Protection Agency. Office of Water. Method 1693: Cryptosporidium and Giardia in disinfected wastewater by concentration/IMS/IFA, Office of Water (4303T) EPA 821-R-14-013. https:// www.epa.gov/sites/ production/files/2015-08/documents/method_1693_2014.pdf

van Doorn AS, Meijer B, Frampton CMA, Barclay ML, de Boer NKH (2020) Systematic review with meta-analysis: SARS-CoV-2 stool testing and the potential for faecal-oral transmission. Aliment Pharmacol Ther 52(8):1276-1288

Villacorta-Martínez de Maturana I, Ares-Mazás ME, Durán-Oreiro D, Lorenzo-Lorenzo MJ (1992) Efficacy of activated sludge in removing Cryptosporidium parvum oocysts from sewage. Appl Environ Microbiol 58:3514-3516

Wang XW, Li J, Guo T, Zhen B, Kong Q, Yi B, Li Z, Song N, Jin M, Xiao W, Zhu X, Gu C, Yin J, Wei W, Yao W, Liu C, Li J, Ou G, Wang M, Fang T, Wang G, Qiu Y, Wu H, Chao F, Li J (2005a) Concentration and detection of SARS coronavirus in sewage from Xiao Tang Shan hospital and the $309^{\text {th }}$ Hospital of the Chinese People's liberation Army. Water Sci Techno 52(8):213-221

Wang XW, Li JS, Jin M, Zhen B, Kong QX, Song N, Xiao WJ, Yin J, Wei W, Wang GJ, Si BY, Guo BZ, Liu C, Ou GR, Wang MN, Fang TY, Chao FH, Li JW (2005b) Study on the resistance of severe acute respiratory syndrome-associated coronavirus. J Virol Methods 126(1-2): 171-177

Wang X, Zheng J, Guo L, Yao H, Wang L, Xia X, Zhang W (2020) Fecal viral shedding in COVID-19 patients: clinical significance, viral load dynamics and survival analysis. Virus Res 289:198147

Ward PI, Deplazes P, Regli W, Rinder H, Mathis A (2002) Detection of eight Cryptosporidium genotypes in surface and waste waters in Europe. Parasitol 124:359-368

Westhaus S, Weber FA, Schiwy S, Linnemann V, Brinkmann M, Widera M, Greve C, Janke A, Hollert H, Wintgens T, Ciesek S (2020) Detection of SARS-CoV-2 in raw and treated wastewater in Germany - suitability for COVID-19 surveillance and potential transmission risks. Sci Total Environ 751:141750

WHO (2016) Quantitative microbial risk assessment: application for water safety management. World Health Organization, Geneva

WHO (2019) Drinking water

Wigginton KR, Ye Y, Ellenberg RM (2015) Emerging investigators series: the source and fate of pandemic viruses in the urban water cycle. Environ Sci Water Res Technol 1:735-746

Wölfel R, Corman VM, Guggemos W, Seilmaier M, Zange S, Müller MA, Niemeyer D, Jones TC, Vollmar P, Rothe C, Hoelscher M, Bleicker T, Brünink S, Schneider J, Ehmann R, Zwirglmaier K,
Drosten C, Wendtner C (2020) Virological assessment of hospitalized patients with COVID-2019. Nature 581(7809):465-469

Wu F, Xiao A, Zhang J, Gu X, Lee WL, Kauffman K, Hanage W, Matus M, Ghaeli N, Endo N, Duvallet C, Moniz K, Erickson T, Chai P, Thompson J, Alm, E (2020a) SARS-CoV-2 titers in wastewater are higher than expected from clinically confirmed cases. mSystems 5(4):e00614-20

Wu F, Xiao A, Zhang J, Moniz K, Endo N, Armas F, Bonneau R, Brown MA, Bushman M, Chai PR, Duvallet C, Erickson TB, Foppe K, Ghaeli N, Gu X, Hanage WP, Huang KH, Lee WL, Matus M, McElroy KA, Nagler J, Rhode SF, Santillana M, Tucker JA, Wuertz S, Zhao S, Thompson J, Alm EJ (2020b) SARS-CoV-2 titers in wastewater foreshadow dynamics and clinical presentation of new COVID-19 cases. medRxiv. https://doi.org/10.1101/2020. 06.15.20117747

Wurtzer S, Marechal V, Mouchel JM, Maday Y, Teyssou R, Richard E (2020a) Evaluation of lockdown impact on SARS-CoV-2 dynamics through viral genome quantification in Paris wastewaters. medRxiv. https://doi.org/10.1101/2020.04.12.20062679

Wurtzer S, Marechal V, Mouchel J, Moulin L (2020b) Time course quantitative detection of SARS-CoV-2 in Parisian wastewaters correlates with COVID-19 confirmed cases. medRxiv. https://doi.org/10. 1101/2020.04.12.20062679

Xagoraraki I, O’Brien E (2020) Wastewater-based epidemiology for early detection of viral outbreaks. Women in Water Quality 2020:7597

Xiao L, Singh A, Limor J, Graczyk TK, Gradus S, Lal A (2001) Molecular characterization of Cryptosporidium oocysts in samples of raw surface water and wastewater. Appl Environ Microbiol 67: $1097-1101$

Xu Y, Li X, Zhu B, Liang H, Fang C, Gong Y, Guo Q, Sun X, Zhao D, Shen J, Zhang H, Liu H, Xia H, Tang J, Zhang K, Gong S (2020) Characteristics of pediatric SARS-CoV-2 infection and potential evidence for persistent fecal viral shedding. Nature Med 26(4): 502-505

Yamashiro S, Foco MLR, Pineda CO, José J, Nour EAA, Siqueira-Castro ICV, Franco RMB (2019) Giardia spp. and Cryptosporidium spp. removal efficiency of a combined fixed-film system treating domestic wastewater receiving hospital effluent. Environ Sci Pollut Res Int 26(22):22756-22771

Yang Z, Xu G, Reboud J, Kasprzyk-Hordern B, Cooper JM (2017) Monitoring genetic population biomarkers for wastewater-based epidemiology. Anal Chem 89(18):9941-9945

Yaqub T, Nawaz M, Shabbir M, Ali MA, Altaf I, Raza S, Shabbir MA, Ashraf MA, Aziz SZ, Cheema S, Shah MB, Hassan S, Rafique S, Sardar N, Mehmood A, Aziz MW, Fazal S, Khan N, Khan MT, Attique M, Asif A, Anwar M, Awan NA, Younis MU, Bhatti MA, Tahir Z, Mukhtar N, Sarwar H, Rana MS (2020) A longitudinal survey for genome-based identification of SARS-CoV-2 in sewage water in selected lockdown areas of Lahore city, Pakistan; a potential approach for future smart lockdown strategy medRixv https:// doi.org/10.1101/2020.07.31.20165126

Ye Y, Ellenberg RM, Graham KE, Wigginton KR (2016) Survivability, partitioning, and recovery of enveloped viruses in untreated municipal wastewater. Environ Sci Technol 50(10):5077-5085

Zahedi A, Gofton AW, Greay T, Monis P, Oskam C, Ball A, Bath A, Watkinson A, Robertson I, Ryan U (2018) Profiling the diversity of Cryptosporidium species and genotypes in wastewater treatment plants in Australia using next generation sequencing. Sci Total Environ 644:635-648

Zahedi A, Greay TL, Paparini A, Linge KL, Joll CA, Ryan UM (2019) Identification of eukaryotic microorganisms with $18 \mathrm{~S}$ rRNA nextgeneration sequencing in wastewater treatment plants, with a more targeted NGS approach required for Cryptosporidium detection. Water Res 158:301-312 
Zahedi A, Ryan U (2020) Cryptosporidium - an update with an emphasis on foodborne and waterborne transmission. Res Vet Sci 132:500512

Zhou L, Singh A, Jiang J, Xiao L (2003) Molecular surveillance of Cryptosporidium spp. in raw wastewater in Milwaukee: implications for understanding outbreak occurrence and transmission dynamics. J Clin Microbiol 41(11):5254-4257

Publisher's note Springer Nature remains neutral with regard to jurisdictional claims in published maps and institutional affiliations. 